\title{
The impact of corporate tax avoidance on analyst coverage and forecasts
}

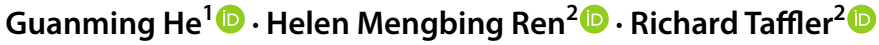

Published online: 26 February 2019

(c) The Author(s) 2019

\begin{abstract}
Corporate tax avoidance is likely to be associated with a high level of earnings management and with high financial opacity in the time-series. On this basis, we hypothesize that analyst coverage is negatively associated with corporate tax avoidance. Our results confirm this conjecture, and are robust to using a firm-fixed-effects model and a quasi-natural experiment to control for potential endogeneity. Additional analysis shows that analyst coverage is negatively related to tax risk, but there is no evidence that the informativeness of, or errors in, analyst forecasts are associated with tax avoidance. Overall, our study advances understanding of the implications of corporate tax avoidance for analyst behavior.
\end{abstract}

Keywords Tax planning $\cdot$ Financial opacity $\cdot$ Analyst following $\cdot$ Earnings forecasts

JEL classifications $\mathrm{G} 24 \cdot \mathrm{H} 26 \cdot \mathrm{M} 41$

\section{Introduction}

Corporate tax avoidance practices are prevalent. Hanlon and Heitzman (2010) define tax avoidance in a broad sense as "the reduction of explicit taxes" (2010, p. 137), and call for more research in this area. Prior studies (e.g. Lev and Nissim 2004; Weber 2009; Goh et al. 2016) show that income tax expense contains information about the future earnings and economic performance of a firm. As such, tax-related information should affect financial analysts' decision-making. However, little research attention to date has been paid to the impact of corporate tax avoidance on analysts' judgements and decisions. The purpose of our study is to examine the impact of corporate tax avoidance on analyst coverage and forecasts; this should be a worthy goal for both academics and practitioners given the pivotal role analysts play as information intermediaries in stock markets.

Earnings management, given its key role in shaping both managerial tax avoidance behavior and analyst behavior, is the crucial channel through which tax avoidance affects analyst coverage and forecasts. The prevailing literature (e.g. Erickson et al. 2004; Frank

Guanming He

guanming.he@durham.ac.uk

1 Durham University Business School, Durham University, Mill Hill Lane, Durham DH1 3LB, UK

2 Warwick Business School, University of Warwick, Scarman Road, Coventry CV4 7AL, UK 
et al. 2009; Desai and Dharmapala 2009; Lennox et al. 2013) documents that earnings management and associated financial opacity have an adverse impact on analyst decisionmaking, a view that is in line with intuition. However, it is unclear whether firms undertaking aggressive financial reporting are more, or less, aggressive in their tax planning (e.g. Bradshaw et al. 2001; Elgers et al. 2003; Abarbanell and Lehavy 2003; Burgstahler and Eames 2003; Barth and Hutton 2004; Hodder et al. 2008; Salerno 2014). ${ }^{1}$

Indeed, the prior evidence on the association between corporate tax avoidance and earnings management is mixed. Some studies suggest a positive association between corporate tax avoidance and earnings management. For instance, Frank et al. (2009) show that corporate tax avoidance facilitates earnings management and increases the financial opacity of a firm. Other papers (e.g. Erickson et al. 2004; Lennox et al. 2013), however, find that tax-avoiding firms are less likely to pursue aggressive financial reporting. Managing concurrently book income upwards, and taxable income downwards, leads to a large book-tax difference, which can raise a "red flag" of financial misrepresentation or of tax avoidance to outsiders (e.g. Palepu et al. 2000; Hanlon 2005; Kuo and Lee 2016). Thus, in an attempt to avoid outsiders' suspicions of accounting fraud or of tax avoidance, managers seek to increase corporate tax payments when inflating book income numbers, leading to a negative relation between tax avoidance and earnings management.

In this paper, we argue that there is likely to be a positive time-series relation between corporate tax avoidance and earnings management, but that the contemporaneous association between the two in the cross-section is likely to be negative. We posit that firms tend to refrain from avoiding income taxes and manipulating earnings in the same fiscal period, because doing so increases book-tax differences, likely attracting scrutiny from tax authorities and other external stakeholders. However, managers could pursue earnings management in one period and tax avoidance in another. Such alternating use of tax avoidance and earnings management across different periods reduces the likelihood of being detected, thereby facilitating concealment of bad news and of managerial misbehavior. Were managers to inflate earnings in the current period, suspicions of low earnings quality would arise from any subsequent downwards reversal of earnings. However, avoiding corporate taxes in the next period could mitigate this fall in earnings. Analyst earnings forecasts are normally based on the historical trend in firms' financial information (e.g. Bradshaw et al. 2014; Palepu et al. 2016). Thus, in the presence of corporate tax avoidance, financial information used by analysts in forecasting will be more opaque.

Prior studies (e.g. Lang and Lundholm 1996; Healy et al. 1999) document that firms with more information available or more informative disclosures have higher analyst coverage. The number of analysts following a firm depends critically on the net benefits of providing analyst services (Bhushan 1989). High financial opacity of a tax-avoiding firm increases the information acquisition and processing costs required of analysts in making unbiased earnings forecasts, thus dis-incentivizing analyst coverage. Furthermore, because of increased risks of inaccurate forecasts and associated reputation issues, analysts would be less likely to cover tax-avoiding firms that tend to have high financial opacity and more financial reporting errors. Therefore, we hypothesize that the level of analyst coverage is negatively correlated with the extent of corporate tax avoidance.

In our empirical analysis, we construct two proxies for corporate tax avoidance: the long-run cash effective tax rate of Dyreng et al. (2008) and the residual domestic book-tax

1 In this study, the term, tax aggressiveness, is used synonymously with tax avoidance. 
difference as per Desai and Dharmapala (2006). Our sample period covers the years of 1995-2014 with 29,372 firm-year observations. After controlling for a broad set of determinants of analyst coverage, we find economically and statistically significant results consistent with our prediction that analyst coverage is negatively associated with corporate tax avoidance. This inference remains unchanged when we use a firm-fixed-effects regression model to control for potential correlated-omitted-variables bias.

To better establish causality for the effect of corporate tax avoidance on analyst coverage, we follow Hasan et al. (2014) in conducting a quasi-natural experiment that is based on the enactment of Financial Accounting Standard Board Interpretation No.48 (hereafter, FIN48) (FASB 2006). We assign firms that report tax reserves for uncertain tax benefits in the post-FIN48 period as treatment firms (which feature higher corporate tax avoidance), and firms that do not report any uncertain tax position in both the pre- and post-FIN48 periods as control firms (which feature little tax avoidance). In line with Blackwell et al. (2009) and Iacus et al. (2011), we employ a coarsened exact matching approach to match each treatment firm with a control firm for our natural experiment. Using a differencein-differences research design, we find that analyst coverage is significantly lower for the treatment firms than for the control firms, thus corroborating the negative causal impact of corporate tax avoidance on analyst coverage.

We also conduct additional tests to explore: (i) the impact of tax risk on analyst coverage, (ii) the impact of corporate tax avoidance on the informativeness of analyst earnings forecasts, and (iii) the impact of corporate tax avoidance on analyst forecast errors. First, to explore the impact of firm tax-position volatility on analyst behavior, we construct a measure of tax risk in terms of the standard deviation of a firm's effective tax rates over the previous 5 years (e.g. Guenther et al. 2017; Drake et al. 2019). Financial opacity is higher for firms with more volatile tax planning activities, making it more difficult for analysts to cover such firms. Thus, we expect a negative relationship between tax risk and analyst coverage. Our results confirm this. Second, following Frankel et al. (2006), we define the informativeness of analyst earnings forecasts as the magnitude of the stock price reaction to these forecasts. We find no evidence that corporate tax avoidance increases stock price reactions to analyst earnings forecasts, implying that corporate tax avoidance does not trigger higher investor demand for analyst services. One potential explanation is that investors are often unable to observe corporate tax avoidance and to understand its adverse impact on a firm's financial transparency. Third, inter alia for reputation reasons, analysts often choose to cover firms for which they feel confident in making accurate forecasts (Das et al. 2006; Franco et al. 2015). For a tax-avoiding firm that analysts opt to cover, they might incur incrementally higher information gathering and/or processing costs to maintain forecast accuracy. As a result, notwithstanding the greater financial opacity that results from tax avoidance, actual analyst forecast errors may not increase. Consistent with this notion, we do not find evidence that corporate tax avoidance increases analyst forecast errors.

This study makes several contributions. First, to the best of our knowledge, this paper is the first to examine the impact of corporate tax avoidance on analyst coverage and forecasting behavior. In particular, we show that corporate tax avoidance leads to lower analyst coverage but does not materially impact analyst earnings forecasting ability for covered firms.

Importantly, we reconcile the mixed prior evidence on the relation between tax avoidance and earnings management by arguing that the association between the two is negative in the cross-section but positive in the time-series. Because analysts rely on the historical trend in financial information in making their earnings forecasts (e.g. Bradshaw et al. 2014; Palepu et al. 2016), corporate tax avoidance is likely to have an adverse impact on analyst 
coverage. Our results confirm this. Recent studies by Allen et al. (2016), Chen and Lin (2017), and Chen et al. (2018) examine the effects of analyst coverage on tax aggressiveness; our paper investigates a different research issue, i.e., the causal impact of corporate tax avoidance on analyst coverage. Our natural experiment design used to establish this causality relationship is in line with Hasan et al. (2014).

Second, we complement the tax literature on the consequences of corporate tax avoidance. Prior studies (e.g. Chen et al. 2010; Graham et al. 2014; Menichini 2017; Cen et al. 2017) document that the main benefit of corporate tax avoidance to a firm lies in the tax savings and associated increased cash flow. However, there are potential negative consequences to corporate tax avoidance, including reputational losses (Chen et al. 2010; Hanlon and Slemrod 2009), tax examination costs (Mills 1998; Mills and Newberry 2001), increased litigation risk (Graham and Tucker 2006), increased audit fees (Hanlon et al. 2012; Donohoe and Knechel 2014; Kuo and Lee 2016), substantive penalties imposed by tax authorities (Wilson 2009; Li et al. 2018), reduction in shareholder wealth due to managerial rent extractions (Desai and Dharmapala 2006, 2009), heightened stock price crash risk (Kim et al. 2011), and an increase in cost of capital (e.g. Hasan et al. 2014; Isin 2018). We extend this tax-consequences literature by showing that corporate tax avoidance also leads to a decline in analyst coverage.

Last, but not least, our study has practical implications. Specifically, managers' alternate use of tax avoidance and earnings management can facilitate and mask their rent extraction, arguably leading to resource misallocation in financial markets. By showing that corporate tax avoidance has an adverse impact on firm coverage by financial analysts who are key information intermediaries, we flag concerns about potential reduced market efficiency. Our findings should thus be of interest to, among other parties, shareholders in their monitoring of managerial opportunism, and regulators and tax authorities seeking to better regulate corporate taxation and associated disclosure policies. One way to curb managers' tax avoidance activities, as suggested by Kuo and Lee (2016), is to increase the conformity between book and taxable income measures.

The remainder of this paper proceeds as follows. Section 2 develops our hypothesis. Section 3 describes our sample and research design. Section 4 discusses our empirical results. Section 5 carries out additional analyses, and Sect. 6 concludes.

\section{Hypothesis development}

Analysts play an important role in capital markets: they provide forecasts and stock recommendations to investors to aid their investment decisions (Marcus and Wallace 1991; Lin et al. 2018; Aggarwal et al. 2018). In this paper, we explore the consequences of corporate tax avoidance on analyst behavior. Our main thesis is that corporate tax avoidance leads to reduced information transparency and to greater difficulty in forecasting earnings, thus reducing analyst incentives to follow firms. Despite an extensive literature on corporate tax avoidance, its impact on analyst coverage has not been explored in the literature. In this section, we derive our main hypothesis and discuss related issues.

\subsection{Corporate tax avoidance and information opacity}

Extant academic research documents that corporate tax aggressiveness reduces the quality of the information environment of firms, rendering corporate information more opaque. 
For example, corporate tax avoidance involves complex tax transactions and thus can be used to hoard bad news associated with managerial rent extraction, leading to such rent extraction going undetected for extended periods (Desai and Dharmapala 2006, 2009; Kim et al. 2011). Comprix et al. (2011) show that large book-tax differences, which proxy for corporate tax avoidance, are associated with greater uncertainty about a firm's fundamentals, and with an increased difference in opinion among investors. Hope et al. (2013) find that corporate tax avoidance is associated with fewer disclosures of geographic earnings by U.S. multinational firms, leading to reduced earnings informativeness (Hope et al. 2009). By and large, the empirical evidence illustrates the adverse impact of tax avoidance on corporate information transparency, with potential implications for analyst behavior.

\subsection{Corporate tax avoidance and earnings management}

Earnings management adversely affects the quality of analysts' earnings forecasts. Although extant research examines the relation between corporate tax avoidance and earnings management, the results are mixed. Some researchers argue that tax avoidance is accompanied by earnings manipulation. For example, Frank et al. (2009) document a positive association between aggressive tax reporting and aggressive financial reporting, suggesting that managers tend to make financial and tax decisions in a way that boosts financial reporting income and reduces taxable income. Similarly, Desai and Dharmapala $(2006,2009)$ show that managers reduce taxable income and inflate earnings in the dualreporting setting. On the other hand, other studies document that corporate tax avoidance is negatively related to earnings management. For example, Lennox et al. (2013) predict, and find, that tax- aggressive firms are less likely to engage in fraudulent financial reporting. Erickson et al. (2004) find that firms committing accounting fraud pay more taxes on their fraudulently reported earnings, which suggests that firms regard the benefits from inflating earnings as outstripping the additional tax costs incurred.

In the face of the conflicting evidence on the association between corporate tax avoidance and earnings management, we contend that the lead-lag association between tax avoidance and earnings management is likely positive in the time-series, but that the contemporaneous relation between the two is likely negative in the cross-section. We postulate that managers are less likely to engage in aggressive tax planning and earnings management simultaneously, because any conspicuous increased book-tax difference resulting would likely cause outsiders to suspect that the managers have either inflated earnings or avoided income taxes.

Instead, managers may manipulate earnings in one period, and avoid corporate income taxes in another, so that book-tax differences will not appear significantly increased, as compared with implementing tax avoidance policies and earnings management in the same fiscal period. On the one hand, earnings inflation might be preceded by tax avoidance in managerial strategies designed to disguise bad news associated with rent extraction (Desai and Dharmapala 2006, 2009). Though tax avoidance can be used as a tool to conceal bad news (Kim et al. 2011), it is hard for managers to iterate tax avoidance in consecutive years without being detected by the tax authorities. So, in an attempt to hoard bad news over an extended period, managers may pursue tax avoidance in a particular year, and alternate this with upwards earnings management in the following year. On the other hand, tax avoidance could in turn follow earnings inflation to window-dress firm performance. Earnings inflated in one period are likely to attract suspicion by outsiders once the inflated earnings 
reverse in the subsequent year; however, an increase in cash flow due to tax avoidance activities can help mitigate the adverse effects of such earnings reversals.

All in all, the alternating use of tax avoidance and earnings management strategies across different years could serve to distract the attention and vigilance of outsiders, thereby allowing managers to take advantage of self-serving opportunities. Such a covert strategy would render corporate information more opaque and less understandable in the time-series. Analysts form their earnings forecasts based on the trend in a firm's financial figures over several years rather than on the firm's financial report for a particular year (e.g. Bradshaw et al. 2014; Palepu et al. 2016). Therefore, corporate tax avoidance will serve to obfuscate the financial information used by analysts in their earnings forecasts, making accurate forecasting more difficult, and potentially leading to analysts' reluctance to follow such tax-aggressive firms.

\subsection{The effect of corporate tax avoidance on analyst coverage}

The fundamental drivers of analyst coverage are the supply of, and demand for, analyst services (Bhushan 1989; Frankel et al. 2006). From the "supply-curve" perspective, the supply of analyst services depends on the information acquisition and processing costs analysts incur in providing their forecast services. Research suggests that analysts tend to follow more transparent firms, since these firms are less costly to follow (Chang et al. 2006; Yu 2008; Irani and Oesch 2013). For instance, Yu (2008) shows that earnings management activities reduce analyst coverage as analysts need to exert more effort, and incur more costs, in penetrating the resulting more opaque financial disclosures.

Forecast accuracy is an important determinant of an analyst's compensation and career prospects (Stickel 1990; Mikhail et al. 1999; Hong and Kubik 2003; Ke and Yu 2006; Emery and Li 2009; Wu and Zang 2009; Brown et al. 2015; Roger 2018). For example, Stickel (1990) shows that earnings forecast accuracy is viewed as an important indicator of analyst ability, and that "All-Star" analysts who make more accurate earnings forecasts are paid more than their peers. Mikhail et al. (1999) find that the probability of analyst turnover increases for those analysts with lower forecast accuracy relative to their peers that follow the same firm. Therefore, analysts have an incentive to make more accurate forecasts.

Corporate tax avoidance not only makes financial information itself more opaque, as documented in prior research (e.g. Desai and Dharmapala 2006; Graham and Tucker 2006; Kim et al. 2011; Hope et al. 2013; Crabtree and Kubick 2014), but also is likely associated with a higher level of earnings management activities in the time-series, as discussed in the previous section. As a result, ceteris paribus, it becomes more difficult for analysts to make accurate forecasts. Put differently, to maintain forecast accuracy for a tax-aggressive firm, analysts have to incur higher information gathering and/or processing costs, thereby reducing their incentive to follow the firm. If, on the other hand, analysts are not prepared to incur the increased costs for a tax-aggressive firm, their forecasts will be less accurate, harming their reputation as well as compensation and career prospects. Therefore, more tax-aggressive firms are less attractive to financial analysts. The main hypothesis of our paper based on the supply-curve argument follows:

\section{H1: Analyst coverage is negatively associated with corporate tax avoidance}

On the other hand, when a firm's financial information becomes more opaque as a result of its tax avoidance activities, there is likely to be an increased investor demand for analyst 
services, which should in turn lead to greater analyst coverage. This "demand-curve" argument, however, is based on the assumption that investors are able to observe corporate tax avoidance and to understand its adverse impact on a firm's financial transparency. Such an assumption does not necessarily hold. Investors, who are generally constrained in their information processing abilities and do not have access to private information, are usually unable to observe complex tax avoidance transactions; high information opacity resulting from corporate tax avoidance is often difficult to see through in the absence of necessary information provision and appropriate professional expertise. In addition, analysts might not be sufficiently sophisticated to appreciate the implications of corporate tax avoidance for future earnings. Therefore, the demand-curve argument, which posits that corporate tax avoidance will trigger higher investor demand for analyst services, is intuitively less persuasive. We also test and refute this argument in Sect. 5.2. ${ }^{2}$ Nonetheless, we employ the supply-curve argument to establish $\mathrm{H} 1$ as intuitively more plausible.

\section{Sample and research design}

In this section, we describe our data sample, variables, and research design.

\subsection{Data sources and sample}

Because the release dates of analyst forecasts are not accurately represented in the $\mathrm{I} / \mathrm{B} / \mathrm{E} / \mathrm{S}$ detail file prior to 1995 (Frankel et al. 2006; Clement et al. 2011), our sample period begins in that year; it ends in 2014. As with prior research (e.g. Frankel et al. 2006; Cheng and Subramanyam 2008; Batta et al. 2016; Jin et al. 2016), we focus on firm coverage and forecasts by sell-side analysts. Data on the analyst coverage and forecasts are obtained from I/B/E/S. Data on institutional holdings are collected from Factset. Other data are taken from CRSP and Compustat. We require that firm-year observations have necessary data available on CRSP, Compustat, I/B/E/S, and Factset to construct the variables of interest for our empirical tests. Our final sample used for testing the impact of corporate tax avoidance on analyst coverage consists of 29,372 firm-year observations for 7285 unique firms.

\subsection{Measures of corporate tax avoidance}

We use two corporate tax avoidance measures in our main tests. The first is the long-run effective tax rate (lretr) as per Dyreng et al. (2008). This is computed as the sum of corporate income tax paid, divided by the sum of a firm's pre-tax income net of special items, over the previous 5 years. High lretr indicates low corporate tax avoidance. It is hard for managers to avoid corporate income taxes in successive years without being detected. Hence, volatile tax positions are likely to reflect managers' tax planning strategies. Use of a one-year effective tax rate to measure the extent of corporate tax avoidance inevitably involves measurement errors. The long-run effective tax rate gets around this measurement issue. Also, the use of this long-term measure fits well with our conceptual argument that

\footnotetext{
${ }^{2}$ In fact, in contrast to our strong evidence consistent with the supply-curve argument, Sect. 5.2 finds no empirical support for the demand-curve argument.
} 
managers are likely to use earnings management and tax avoidance alternately in different years for opportunistic purposes.

Our second tax avoidance measure is the residual domestic book-tax difference (ddmpbtd) of Desai and Dharmapala (2006), which is calculated as the residual, $\varepsilon_{i, t}$, of the following firm-fixed-effects regression model:

$$
\operatorname{mpbtd}_{i, t}=\beta_{1} t a_{i, t}+u_{i}+\varepsilon_{i, t}
$$

where mpbtd is the Manzon and Plesko (2002) book-tax difference. In calculating mpbtd, we follow Cheng et al. (2012) in excluding foreign tax expense from the total current tax expense. $t a$ is total accruals calculated as per Hribar and Collins (2002). $u_{i}$ represents firmfixed effects which control for the effect of unobserved firm characteristics on mpbtd. A large book-tax difference could result from either upwards earnings management or corporate tax avoidance (Kuo and Lee 2016). The Desai and Dharmapala (2006) measure purges the book-tax difference attributed to earnings management activities, and thus is more powerful than the Manzon and Plesko (2002) book-tax difference (mpbtd) in capturing the extent of corporate tax avoidance. High ddmpbtd indicates a high level of corporate tax avoidance.

\subsection{Multivariate tests of $\mathrm{H} 1$}

To test the effect of corporate tax avoidance on analyst coverage, we start by using the following pooled OLS regression model:

$$
\text { lanacov }_{i, t}=\alpha_{0}+\alpha_{1} \operatorname{lretr}_{i, t}\left(\text { ddmpbtd }_{i, t}\right)+\sum_{k} \alpha_{i, k} \text { controls }_{i}^{k}+\text { YearDummies }+\varepsilon_{i, t}
$$

where lanacov is analyst coverage, calculated as the natural logarithm of one plus the number of analysts that make at least one annual EPS forecast for a firm in a fiscal year. lana$c o v$ is equal to 0 if there is no analyst forecasting annual EPS for the firm in a particular year. ddmpbtd and lretr are defined as previously. Because a high (low) value of ddmpbtd (lretr) represents a high level of corporate tax avoidance, we expect that if the coefficient on ddmpbtd (lretr) has a negative (positive) sign and is statistically significant, then our results support $\mathrm{H} 1$.

Model (2) also includes a wide range of control variables that prior literature finds to be associated with analyst coverage. Bhushan (1989) claims that larger firms are more attractive to outside investors, spurring the demand for analyst services for these firms, and leading to greater analyst following. Thus, we control for firm size (size) and predict it to be positively correlated with analyst coverage. Brokerage houses are likely to encourage their analysts to cover more actively traded firms (Frankel et al. 2006), hence we include trading volume (tradingvol) as a control variable, and predict its positive relation with analyst coverage.

We control for three proxies for firm-specific uncertainty: equity beta (beta), return volatility (retvol), and earnings volatility (stdeps), which should be positively associated with investor demand for analyst services and thus with increased analyst coverage (Bhushan 1989). On the other hand, analysts might have weak incentives to follow firms that have high stock price or high abnormal stock returns (Brennan and Hughes 1991), because such firms might underperform in subsequent periods. Thus, we also control for stock price (price) and abnormal stock returns (qtrret) in our model, and expect these two variables to be negatively related to analyst coverage. 
Analysts prefer to cover highly-profitable and financially-healthy firms (e.g. Das et al. 2006; Lee and So 2017). Thus, we control for pre-tax return on assets (roa) and financial constraints $(h p) .^{3}$ The higher (lower) a firm's pre-tax return on assets is (financial constraints are), the more likely analysts are to follow the firm. We also control for institutional ownership (insti), but the direction of the effect of institutional ownership on analyst coverage is ambiguous. If institutions rely on analyst reports to make their trading decisions and to fulfil their fiduciary responsibilities, greater institutional stock-holding should induce more analyst following (O'Brien and Bhushan 1990). Nonetheless, institutions are arguably sophisticated investors who are able to predict future firm performance and stock returns (Gompers and Metrick 2001; Cohen et al. 2002; Yan and Zhang 2009). In addition, institutions also serve a monitoring role (Chen et al. 2007), prompting firms to disclose more relevant information to the public (Healy et al. 1999; Ajinkya et al. 2005), and thereby reducing investor demand for analyst services. As such, analysts might be less inclined to cover a firm with high institutional ownership.

Prior studies (e.g. Lang and Lundholm 1996; Chang et al. 2006; He et al. 2019) provide evidence that analyst coverage is related to information asymmetry. Therefore, we include in our regression model research and development expenditures $(r d)$, intangible assets (intangible), and book-to-market ratio $(\mathrm{btm})$, which are used in prior literature as proxies for information asymmetry. Firms that have higher research and development expenditures, more intangible assets, or lower book-to-market ratios are likely to have greater information asymmetry with outsiders (Smith and Watts 1992; Aboody and Lev 2000; Gu and Wang 2005; Huddart and Ke 2007), and are thus expected to be followed by fewer analysts.

We also consider the impact of Regulation Fair Disclosure (FD), which prohibits firms from selectively releasing private information to analysts. Absent private information from management, analysts have to incur higher information acquisition and/or processing costs to maintain forecast accuracy, and as a result, they might be less willing to cover firms (Irani and Karamanou 2003; Mohanram and Sunder 2006; Chen et al. 2016). We therefore use an indicator variable for the post-FD period $(f d)$ in our regression. Finally, as analysts prefer to follow firms that are in more regulated industries (O'Brien and Bhushan 1990), we include an indicator variable for industrial regulatory status (regulated). All our control variables are defined in detail in the Appendix. While including year dummies in the regression to control for potential time effects, we cluster the standard errors of our regression coefficients by both firm and year to control for possible correlations of residuals within firms and years (Gow et al. 2010; Thompson 2011).

Although we include an extensive list of control variables in the regression, we cannot completely exclude the possibility that our regression model still omits some variables that might be related to both corporate tax avoidance and analyst coverage. To address this concern, we re-estimate model (2) using the firm-fixed-effects regression technique, which holds unobserved firm characteristics constant and thereby alleviates endogeneity attributed to potentially omitted variables (e.g. Wooldridge 2016).

\subsection{Control for endogeneity-A quasi-natural experiment (FIN48)}

To strengthen our inferences and explore in more detail the causal relationship between corporate tax avoidance and analyst coverage, we also conduct a quasi-natural experiment.

\footnotetext{
${ }^{3}$ All our multivariate results hold if we drop all firm-year observations with negative pre-tax earnings.
} 
Recent tax research (e.g. Robinson and Schimidt 2013; Brown et al. 2016; Gupta et al. 2016) considers an alternative measure of corporate tax avoidance, namely, unrecognized tax benefits (hereafter, UTB). UTB stands for tax reserves for uncertain tax positions, which might or might not be sustained upon IRS audit. UTB can potentially capture corporate tax avoidance activities that might be opposed by tax authorities (e.g. Lisowsky et al. 2013). The Financial Accounting Standards Board Interpretation No. 48 (i.e., FIN48) (FASB 2006), which relates to the appropriate accounting treatment for UTB, was implemented in June 2006 and became effective from December 2006. Prior to FIN48, firms were reluctant to disclose their UTB because it reflects their tax aggressiveness (Gleason and Mills 2002). Following FIN48, all firms are required to fully disclose their UTB, if any. As a result, any uncertain tax-position reserves set up by firms to avoid taxes before FIN48 are publicly disclosed after FIN48, creating information shock with respect to UTB. Furthermore, recent studies (e.g. Robinson et al. 2016, 2017; Gleason et al. 2018) provide evidence that FIN48 lowers the informativeness and value relevance of corporate tax disclosures. Therefore, the promulgation of FIN48 provides a nice natural experiment to examine the causal impact of corporate tax avoidance on analyst following.

Hasan et al. (2014) use FIN48 to conduct a natural experiment to examine the causal impact of corporate tax avoidance on the cost of bank loans. Following Hasan et al. (2014), we define a treatment firm as a firm that discloses UTB in any of the 3 years after FIN48, and a control firm as one that reports no uncertain tax position in both the pre- and postFIN48 periods. Our natural experiment uses data for the three-year period 2003-2005 before FIN48, and the three-year period 2007-2009 after FIN48. In line with H1, if analysts use the increased UTB-based disclosures, which result from the adoption of FIN48, to infer a firm's tax avoidance, then the treatment firms should show a relative decline in analyst coverage after FIN48, compared with the control firms. To test this prediction, we employ the following difference-in-differences (DiD) regression model:

$$
\text { lanacov }_{i, t}=\alpha_{0}+\alpha_{1} y_{u t b_{t}}+\alpha_{2} \text { tutb }_{i}+\alpha_{3} \text { utbinteract }+\sum_{k} \alpha_{i, k} \text { controls }_{i}^{k}+\text { YearDummies }+\varepsilon_{i, t}
$$

where the indicator variable $y u t b$ is used to indicate the pre- versus post-FIN48 periods for our sample: yutb equals to 1 (0) if a firm is in the years of 2007-2009 (2003-2005). We use $t u t b=1(t u t b=0)$ to indicate a firm-year observation being in the treatment (control) group. utbinteract is the interaction term between yutb and tutb. The same set of control variables as in model (2), as well as year and industry dummies, are included in model (3) to perform our difference-in-differences test. We focus on the coefficient on utbinteract because it reflects the difference-in-differences change in analyst coverage between the treatment and control firms across the post- and pre-FIN48 periods. If H1 holds, utbinteract should have a negative, statistically significant coefficient.

A DiD design requires that the assignment of observations into treatment and control groups is random, but FIN48 might affect such an assignment in a way that induces systematic imbalances in pre-FIN48 covariates between our treatment and control groups. To address this concern, we implement the $k$-to- $k$ coarsened exact matching (CEM) approach, as with Blackwell et al. (2009) and Iacus et al. (2011), to match each of our treatment firms with a control firm to form our sample for the DiD analysis. Matching is conducted by estimating the regression of corporate tax avoidance on its determinants which include firm size (size), firm age (firmage), book-to-market ratio (btm), financial leverage (lev), pretax return on assets (roa), property, plant and equipment (ppe), intangible assets (intangible), equity income (equityic), and foreign income (foreignic) (e.g. Cheng et al. 2012; Hope 
et al. 2013; Gao et al. 2016; Cen et al. 2017). 537 matched pairs are identified following the $k$-to- $k$ CEM matching.

Panel A of Table 4 reports the $L 1$ statistics, which are used to check the quality of the matching (e.g. Blackwell et al. 2009; Iacus et al. 2011). The overall $L 1$ statistic for the postmatched sample is 0.6851 , which is substantially lower than that (i.e., 0.9868) for the prematched sample. Also, the $L 1$ statistics of the majority of the covariates are significantly reduced after the matching. Therefore, the quality of our matching is assured.

The DiD design is predicated on the parallel trend assumption that the outcome variable exhibits a similar trend for both the treatment and control groups in the pre-event period. Panel B of Table 4 shows that the average lanacov of the treatment group is statistically indifferent from that of the control group in any year of our pre-FIN48 sample period, thus supporting the parallel trend assumption.

In addition, we also use UTB as an alternative measure of corporate tax avoidance to test H1. We first restrict our sample to span only the post-FIN48 period (i.e., 2007-2014), in which firms are required by FIN48 to disclose any change in tax reserves as adjustments to stockholders' equity. Then we substitute $u t b$ for lretr (ddmpbtd) in Eq. (2) and re-run the regression. The variable, $u t b$, is defined as the natural logarithm of one plus a firm's uncertain tax benefits at the end of a fiscal year. The higher the value of $u t b$, the greater the degree of corporate tax avoidance. Based on H1, we expect the coefficient on utb to be negative and statistically significant at conventional levels.

\section{Empirical results}

Table 1 presents the descriptive statistics of the variables used in our empirical analysis. Due to the data requirements for constructing different tax avoidance measures for the regression analyses, the number of observations differs for lretr, ddmpbtd, utb, and stdetr. ${ }^{4}$ Mean lretr equals 0.1177 , indicating that the average long-run cash effective tax rate is $11.77 \%$. The mean value of $d d m p b t d$ is 0.0457 , indicating that the residual domestic book-tax difference on average accounts for approximately $4.57 \%$ of firms' total assets. The average value of lanacov is 2.3871 , implying that each firm, on average, is followed by approximately 10 analysts in our sample period. Table 2 reports the Spearman correlation coefficients between the independent variables used in our baseline regression. We check the potential multicollinearity issue with our regression estimations by running the variance inflation factor (VIF) test. Un-tabulated results show that the VIF value is less than 5 for all the explanatory variables except the post-FD-period indicator $(f d)$. Further, our regression results hold when not including $f d$ as a control variable. Therefore, multicollinearity is not an issue in our multivariate analyses (O'Brien 2007).

The tests of our main hypothesis H1 (i.e., that increased corporate tax avoidance is associated with reduced analyst coverage), using Eq. (2), are presented in Tables 3 and 4. The former table reports the results of our OLS (firm-fixed-effects) regressions, and the latter shows the results of our natural experiment. The OLS regression results in Columns (1-2) of Table 3 are as predicted. The coefficient for lretr is positive (0.4347) and statistically significant at the $1 \%$ level. The coefficient on ddmpbtd is also statistically significant at the

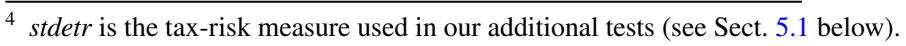


Table 1 Descriptive statistics

\begin{tabular}{|c|c|c|c|c|c|c|c|}
\hline Variable & No. of firm-years & $\begin{array}{l}\text { No. of } \\
\text { unique } \\
\text { firms }\end{array}$ & Mean & Std.dev. & 25 th & Median & 75 th \\
\hline lanacov & 29,372 & 7285 & 2.3871 & 1.6223 & 0.6931 & 2.7081 & 3.6889 \\
\hline car & 23,563 & 5993 & 0.0840 & 0.0605 & 0.0420 & 0.0671 & 0.1065 \\
\hline error & 21,040 & 5328 & 0.1327 & 0.6258 & 0.0012 & 0.0042 & 0.0192 \\
\hline lretr & 29,372 & 7285 & 0.1177 & 0.1424 & 0 & 0.0753 & 0.1885 \\
\hline ddmpbtd & 26,995 & 7150 & 0.0457 & 1.4637 & 0.0003 & 0.0229 & 0.0675 \\
\hline$u t b$ & 1024 & 456 & 2.9683 & 1.9780 & 1.3752 & 2.7652 & 4.3438 \\
\hline stdetr & 23,362 & 6093 & 0.0791 & 0.0816 & 0.0196 & 0.0497 & 0.1148 \\
\hline size & 29,372 & 7285 & 6.0540 & 2.0199 & 4.6563 & 6.0830 & 7.3865 \\
\hline tradingvol & 29,372 & 7285 & $2.06 \mathrm{E}+07$ & $1.13 \mathrm{E}+08$ & $2.37 \mathrm{E}+05$ & $1.87 \mathrm{E}+06$ & $1.06 \mathrm{E}+07$ \\
\hline beta & 29,372 & 7285 & 0.8337 & 0.6043 & 0.3707 & 0.7792 & 1.2154 \\
\hline retvol & 29,372 & 7285 & 0.0314 & 0.0208 & 0.0184 & 0.0262 & 0.0383 \\
\hline stdeps & 29,372 & 7285 & 1.1186 & 102.0946 & 0.0100 & 0.0237 & 0.0659 \\
\hline price & 29,372 & 7285 & 27.4007 & 383.7032 & 7.6800 & 17.7500 & 31.9850 \\
\hline qtrret & 29,372 & 7285 & 0.0204 & 0.7242 & -0.2987 & -0.0512 & 0.2061 \\
\hline roa & 29,372 & 7285 & -0.0206 & 0.1795 & -0.0012 & 0.0117 & 0.0336 \\
\hline$h p$ & 29,372 & 7285 & -1086.26 & 1206.70 & -1800.76 & -501.32 & -131.85 \\
\hline insti & 29,372 & 7285 & 0.5067 & 0.8265 & 0.2255 & 0.5038 & 0.7549 \\
\hline$r d$ & 29,372 & 7285 & 0.0828 & 0.2756 & 0 & 0 & 0 \\
\hline intangible & 29,372 & 7285 & 0.0395 & 0.1076 & 0 & 0 & 0.0099 \\
\hline btm & 29,372 & 7285 & 0.8614 & 2.3669 & 0.3511 & 0.5794 & 0.9189 \\
\hline$f d$ & 29,372 & 7285 & 0.6781 & 0.4672 & 0 & 1 & 1 \\
\hline regulated & 29,372 & 7285 & 0.2917 & 0.4546 & 0 & 0 & 1 \\
\hline
\end{tabular}

This table tabulates the descriptive statistics of the variables used in the hypothesis tests. The sample period ranges from 1995 to 2014. The number of observations used for the test of H1 is 29,372. Due to the data requirements in constructing different tax avoidance measures for the regression analyses, the number of observations differs for lretr, ddmpbtd, utb, and stdetr. All the variables are defined in the Appendix

$1 \%$ level, and has the predicted negative sign $(-0.0144) .{ }^{5}$ On this basis, analyst coverage is negatively associated with corporate tax avoidance; H1 is thus supported. A one-standarddeviation increase in lretr leads to an increase in lanacov by 0.7052 , which is equivalent to $29.54 \%$ of its sample mean and is economically significant. Un-tabulated analysis reveals that t-statistics of all regression coefficients would be substantially different if standard errors are not clustered by both firm and year; this indicates the necessity of doing the two-way clustering to correct for time-series and cross-sectional dependence in residuals (Petersen 2009; Thompson 2011).

Though the pooled OLS regression estimation yields the results consistent with $\mathrm{H} 1$, it cannot identify whether the impact of corporate tax avoidance on analyst coverage comes from explaining variation in analyst coverage across firms (i.e., cross-sectional variation)

\footnotetext{
5 We re-run our regression analysis using the 5-year 2010-2014 period following the global financial crisis, and obtain qualitatively the same results. Specifically, the coefficient for lretr (ddmpbtd) is 0.2442 $(-0.0113)$ and statistically significant at $5 \%(1 \%)$ level.
} 


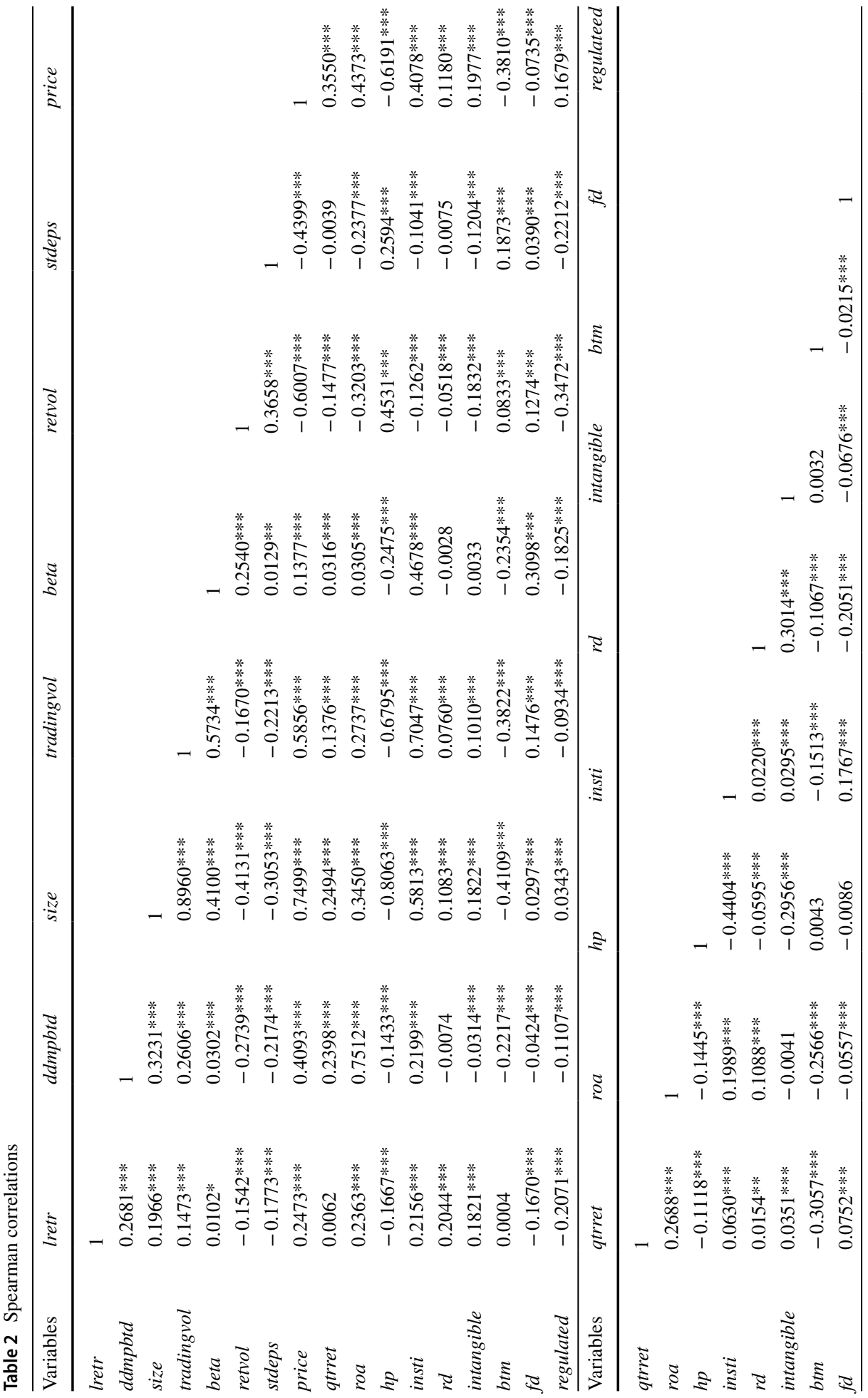




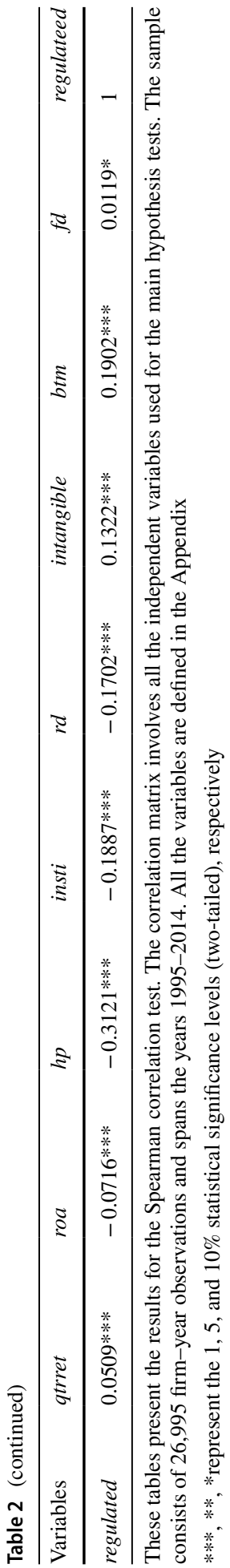

Springer 
Table 3 Test of H1: OLS and firm-fixed-effects regressions of corporate tax avoidance on analyst coverage

\begin{tabular}{|c|c|c|c|c|c|c|c|}
\hline \multirow[t]{3}{*}{ Variables } & \multirow[t]{3}{*}{ Pred. Sign } & \multicolumn{6}{|c|}{ Dependent variable $=$ lanacov } \\
\hline & & \multicolumn{2}{|l|}{ OLS } & \multicolumn{4}{|c|}{ Firm-fixed effects } \\
\hline & & (1) & (2) & (3) & (4) & (5) & (6) \\
\hline lretr & + & $\begin{array}{l}0.4347 * * * \\
(<0.001)\end{array}$ & & $\begin{array}{l}0.2021 * * * \\
(<0.001)\end{array}$ & & $\begin{array}{l}0.2877 * * * \\
(<0.001)\end{array}$ & \\
\hline ddmpbtd & - & & $\begin{array}{l}-0.0144 * * * \\
(<0.001)\end{array}$ & & $\begin{array}{l}-\mathbf{0 . 0 0 5 1} * * * \\
(<0.001)\end{array}$ & & $\begin{array}{l}-0.0043 * * * \\
(<0.001)\end{array}$ \\
\hline size & + & $\begin{array}{l}0.4835^{* * * *} \\
(<0.001)\end{array}$ & $\begin{array}{l}0.4831 * * * \\
(<0.001)\end{array}$ & $\begin{array}{l}0.3926 * * * \\
(<0.001)\end{array}$ & $\begin{array}{l}0.3926 * * * \\
(<0.001)\end{array}$ & & \\
\hline tradingvol & + & $\begin{array}{l}-9.35 \mathrm{E}-11^{*} \\
(0.064)\end{array}$ & $\begin{array}{l}-5.63 E-11 \\
(0.164)\end{array}$ & $\begin{array}{l}-2.09 \mathrm{E}-10^{* *} \\
(0.016)\end{array}$ & $\begin{array}{l}-1.82 \mathrm{E}-10^{* *} \\
(0.011)\end{array}$ & & \\
\hline beta & + & $\begin{array}{l}0.5250 * * * \\
(<0.001)\end{array}$ & $\begin{array}{l}0.5256^{* * *} \\
(<0.001)\end{array}$ & $\begin{array}{l}0.1397 \text { *** } \\
(<0.001)\end{array}$ & $\begin{array}{l}0.1355^{* * *} \\
(<0.001)\end{array}$ & & \\
\hline retvol & + & $\begin{array}{l}1.6843 * \\
(0.055)\end{array}$ & $\begin{array}{l}1.2715 \\
(0.128)\end{array}$ & $\begin{array}{l}2.3519^{* * *} \\
(0.007)\end{array}$ & $\begin{array}{l}2.1935^{* *} \\
(0.012)\end{array}$ & & \\
\hline stdeps & - & $\begin{array}{l}-0.0002^{* * *} \\
(<0.001)\end{array}$ & $\begin{array}{l}-0.0002 * * * \\
(<0.001)\end{array}$ & $\begin{array}{l}-0.0002^{* * *} \\
(<0.001)\end{array}$ & $\begin{array}{l}-0.0002 * * * \\
(<0.001)\end{array}$ & & \\
\hline price & - & $\begin{array}{l}-0.0001^{* * *} \\
(<0.001)\end{array}$ & $\begin{array}{l}-0.0001 * * * \\
(<0.001)\end{array}$ & $\begin{array}{l}7.25 \mathrm{E}-06 \\
(0.339)\end{array}$ & $\begin{array}{l}1.01 \mathrm{E}-05^{*} \\
(0.086)\end{array}$ & & \\
\hline qtrret & - & $\begin{array}{l}-0.1813^{* * *} \\
(<0.001)\end{array}$ & $\begin{array}{l}-0.1799 * * * \\
(<0.001)\end{array}$ & $\begin{array}{l}-0.1602 * * * \\
(<0.001)\end{array}$ & $\begin{array}{l}-0.1550^{* * *} \\
(<0.001)\end{array}$ & & \\
\hline roa & + & $\begin{array}{l}-0.1271^{* * *} \\
(0.007)\end{array}$ & $\begin{array}{l}-0.1040 * * \\
(0.030)\end{array}$ & $\begin{array}{l}-0.2296^{* * * *} \\
(<0.001)\end{array}$ & $\begin{array}{l}-0.2499 * * * \\
(<0.001)\end{array}$ & & \\
\hline$h p$ & - & $\begin{array}{l}-0.0001 * * * \\
(<0.001)\end{array}$ & $\begin{array}{l}-0.0001 * * * \\
(<0.001)\end{array}$ & $\begin{array}{l}-0.0001 * * * \\
(<0.001)\end{array}$ & $\begin{array}{l}-0.0001 * * * \\
(<0.001)\end{array}$ & & \\
\hline insti & $?$ & $\begin{array}{l}0.0877 \\
(0.428)\end{array}$ & $\begin{array}{l}0.0774 \\
(0.449)\end{array}$ & $\begin{array}{l}0.0191 \\
(0.262)\end{array}$ & $\begin{array}{l}0.0178 \\
(0.281)\end{array}$ & & \\
\hline$r d$ & - & $\begin{array}{l}-0.2755^{* * *} \\
(<0.001)\end{array}$ & $\begin{array}{l}-0.2740 * * * \\
(<0.001)\end{array}$ & $\begin{array}{l}0.0655^{*} \\
(0.086)\end{array}$ & $\begin{array}{l}0.0865^{*} \\
(0.050)\end{array}$ & & \\
\hline intangible & - & $\begin{array}{l}-0.0221 \\
(0.708)\end{array}$ & $\begin{array}{l}0.0705 \\
(0.269)\end{array}$ & $\begin{array}{l}0.1063 \\
(0.107)\end{array}$ & $\begin{array}{l}0.1334 * \\
(0.058)\end{array}$ & & \\
\hline btm & + & $\begin{array}{l}-0.0002 \\
(0.934)\end{array}$ & $\begin{array}{l}0.0002 \\
(0.931)\end{array}$ & $\begin{array}{l}0.0217^{* * *} \\
(0.006)\end{array}$ & $\begin{array}{l}0.0223^{* * * *} \\
(0.008)\end{array}$ & & \\
\hline$f d$ & - & $\begin{array}{l}-0.7712 \\
(0.271)\end{array}$ & $\begin{array}{l}-0.7842 \\
(0.281)\end{array}$ & $\begin{array}{l}0.5020 * * * \\
(<0.001)\end{array}$ & $\begin{array}{l}0.2803 * * * \\
(<0.001)\end{array}$ & & \\
\hline regulated & $?$ & $\begin{array}{l}-0.4895^{* * *} \\
(<0.001)\end{array}$ & $\begin{array}{l}-0.5143 * * * \\
(<0.001)\end{array}$ & & & & \\
\hline $\begin{array}{l}\text { Adjusted } \\
\mathrm{R}^{2}\end{array}$ & & 0.5675 & 0.5646 & 0.2553 & 0.2513 & 0.1191 & 0.1202 \\
\hline $\begin{array}{l}\text { Observa- } \\
\text { tions }\end{array}$ & & 29,372 & 26,995 & 29,372 & 26,995 & 29,372 & 26,995 \\
\hline
\end{tabular}

This table reports the results for the tests of H1. Columns (1-2) ((3-6)) report the results from the OLS (firm-fixed-effects) regressions. The sample spans the period of 1995-2014. The dependent variable is analyst coverage, namely, lanacov. The treatment variable is corporate tax avoidance which are proxied by the long-run cash effective tax rate (lretr) and residual domestic book-tax difference (ddmpbtd). All the variables are defined in the Appendix. Because the firm-fixed-effects regression automatically drops any independent variable that exhibits no within-firm variance, regulated is omitted by the firm-fixed-effects test. 
Table 3 (continued)

Year dummies are included in all the regressions but not reported for simplicity. The $p$ values in brackets are based on robust standard errors that are clustered by firm and year (firm) in the OLS (firm-fixed-effects) regressions

The results highlighted in bold are those for the key independent variables of our regressions $* * *, * *$, *represent the 1,5 , and $10 \%$ statistical significance levels (two-tailed), respectively

or variation in analyst coverage within firms (i.e., time-series variation). Conceptual arguments about how analyst coverage is related to corporate tax avoidance predict (i) that firms with a higher degree of tax avoidance are likely to have lower analyst coverage than firms engaging in less tax avoidance activities, which is a cross-sectional prediction, and (ii) that a firm which experiences an increase in tax avoidance activities is likely to be followed by fewer analysts, which pertains to a time-series prediction. A firm-fixed-effects regression, when applied to model (2), removes most of the cross-sectional variation in tax avoidance and relies primarily on the within-firm (i.e., time-series) variation in tax avoidance to test the relationship between analyst coverage and tax avoidance. If the negative association between analyst coverage and tax avoidance, as evidenced by the OLS regression results, is driven mainly by cross-sectional differences, then in using the firmfixed-effects regression, we expect to find no evidence of a relationship between analyst coverage and tax avoidance. In contrast, if within-firm variance in tax avoidance explains within-firm variance in analyst following, we expect to find an association between analyst following and tax avoidance when controlling for firm-fixed-effects in our regression model. Also, in determining whether time-series variation in tax avoidance explains timeseries variation in analyst coverage, our firm-fixed-effects regression alleviates correlatedomitted-variables bias attributable to unobserved firm characteristics.

When including firm-fixed effects, the coefficient on lretr (ddmpbtd), reported in Column (3) ((4)) of Table 3, is again statistically significant at the $1 \%$ level with the predicted positive (negative) sign. Our firm-fixed-effects results, taken together with the OLS results, are thus not only consistent with $\mathrm{H} 1$ but also allow us to go further in suggesting that the negative impact of corporate tax avoidance on analyst coverage can be explained not only by time-series variation in tax avoidance but also by cross-sectional variation in tax avoidance. In Columns (5) and (6), we further report results from a simple firm-fixed-effects regression model that includes either lretr, or ddmpbtd, as the independent variable. Both lretr and ddmpbtd on their own separately appear statistically and economically significant in explaining analyst coverage.

Panel C of Table 4 reports the results of our FIN48-based quasi-natural experiment, which is implemented by running Eq. (3). The coefficient on the key interaction term, utbinteract, in Column (1) is negative and statistically significant at the 5\% level. This indicates that the treatment firms with positive UTB have lower analyst coverage than the control firms which do not report any UTB, again in line with H1. FIN48 triggers an exogenous increase in treatment firms' UTB disclosures. Our findings suggest that analysts are using the increased UTB disclosures of the treatment firms to infer tax avoidance activities, and as a result, reduce coverage of these firms. So the result can be taken as further evidence of the negative, causal impact of corporate tax avoidance on analyst following, again corroborative of H1. In addition, as a robustness check, we use UTB as an alternative proxy for tax avoidance in model (2). Column (2) reports the regression results. The coefficient on $u t b$ is negative $(-0.0877)$ and is statistically significant at the $1 \%$ level, lending additional support for H1. Also, an increase of one standard deviation in $u t b$ leads to a decrease in lanacov by 0.1423 , which accounts for $5.96 \%$ of its mean value and is thus economically significant in magnitude. 
Table 4 Test of H1: Evidence from a quasi-natural experiment (FIN48)

\begin{tabular}{lll}
\hline Variables & Pre-matched L1 statistics & $\begin{array}{l}\text { Post-matched } \\
\text { L1 statistics }\end{array}$
\end{tabular}

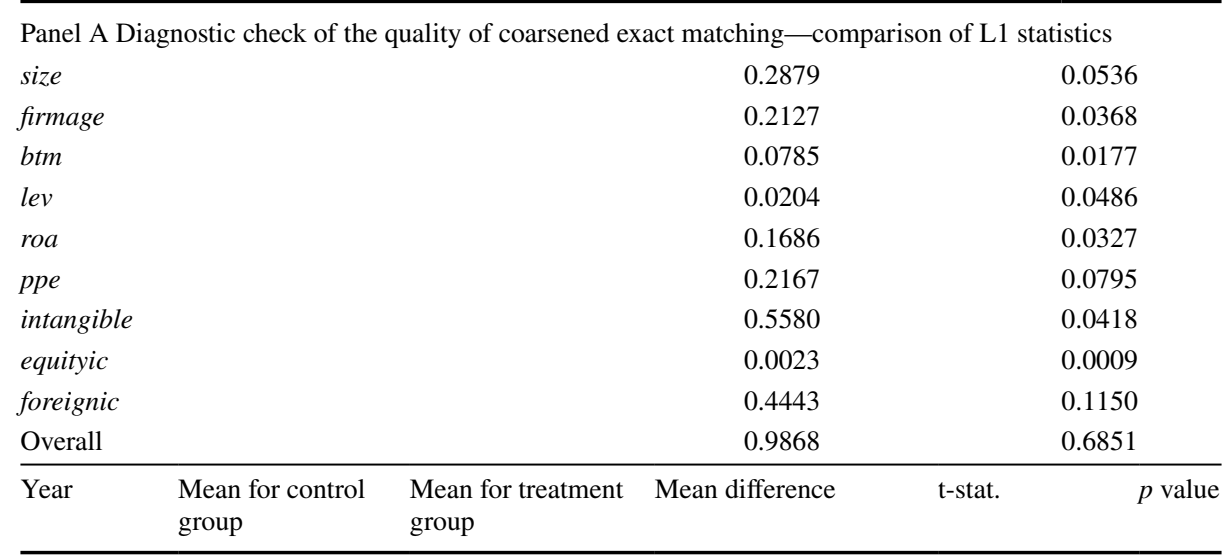

Panel B Diagnostic test of the parallel trend assumption-comparison of the mean of lanacov between the treatment and control groups in the pre-FIN48 period (2003-2005)

\begin{tabular}{llllll}
2003 & 2.6758 & 2.8505 & -0.1746 & -0.8320 & 0.4064 \\
2004 & 2.6932 & 2.9082 & -0.2149 & -1.1329 & 0.2584 \\
2005 & 2.9019 & 2.9954 & -0.0936 & -0.5427 & 0.5878 \\
\hline
\end{tabular}

Variables

Dependent variable $=$ lanacov

(1)

(2)

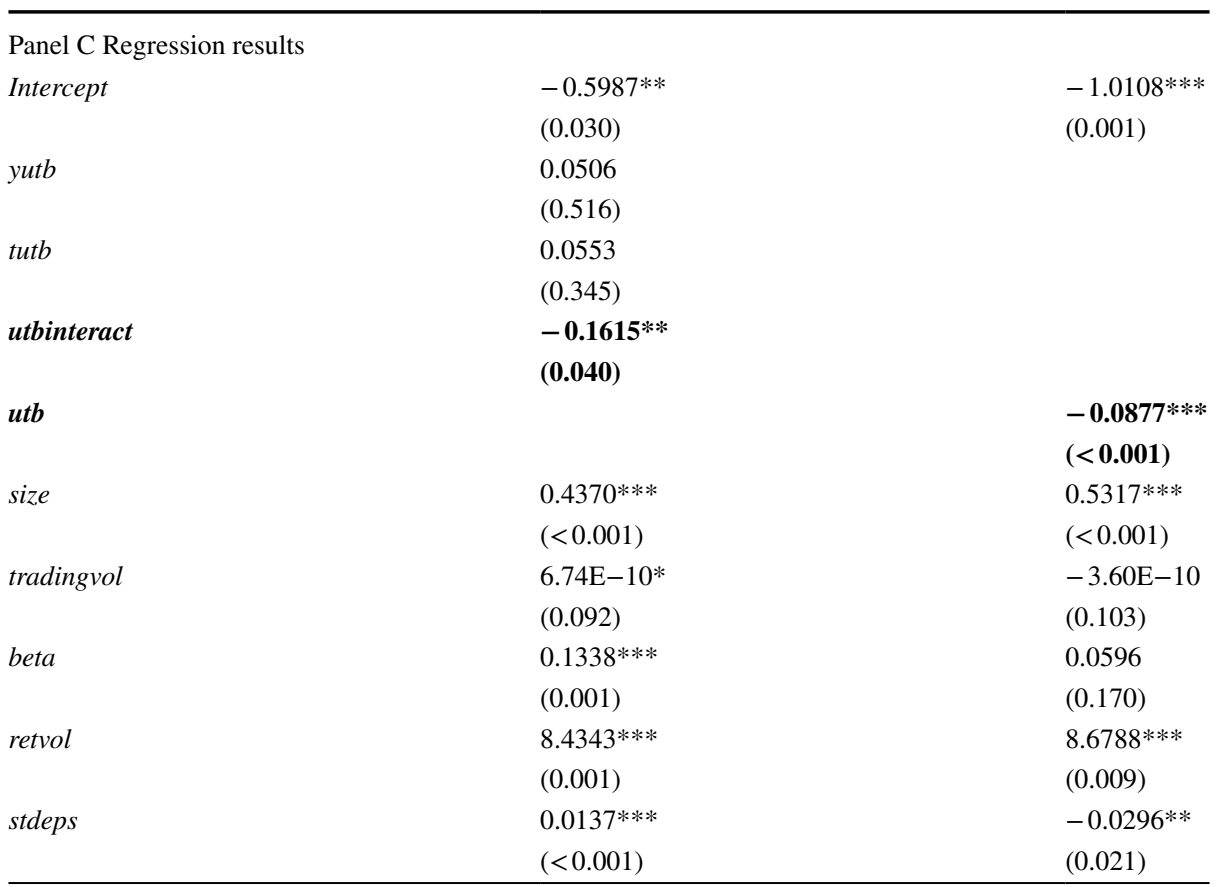


Table 4 (continued)

\begin{tabular}{lll}
\hline Variables & Dependent variable=lanacov & \\
\cline { 2 - 3 } & $(1)$ & $(2)$ \\
\hline price & $-0.0032^{* * *}$ & $-0.0026^{* * *}$ \\
qtrret & $(0.007)$ & $(<0.001)$ \\
& $-0.1828^{* * *}$ & -0.0521 \\
roa & $(<0.001)$ & $(0.147)$ \\
& -0.2891 & $-1.1219^{* * *}$ \\
hp & $(0.128)$ & $(<0.001)$ \\
& $-3.72 \mathrm{E}-05$ & $-0.0001^{* * *}$ \\
insti & $(0.251)$ & $(0.003)$ \\
& $0.6118^{* * *}$ & $0.5351^{* * *}$ \\
rd & $(<0.001)$ & $(<0.001)$ \\
& $-0.0911^{*}$ & -0.0609 \\
intangible & $(0.080)$ & $(0.225)$ \\
& $0.2613^{* * *}$ & $-0.2208^{* * *}$ \\
btm & $(0.024)$ & $(0.024)$ \\
& $0.1542^{* * *}$ & $0.2000^{* * *}$ \\
regulated & $(0.001)$ & $(<0.001)$ \\
Adjusted $\mathrm{R}^{2}$ & -0.4863 & $-0.5782^{* * *}$ \\
Observations & $(0.154)$ & $(<0.001)$ \\
& 0.5737 & 0.6365 \\
Pan & 1106 & 1024
\end{tabular}

Panel A reports the L1 statistics of the covariates used in the regression that is run for coarsened exact matching. Panel B reports the results for the $t$ test of the mean differences in lanacov by year between the treatment and control groups for the pre-FIN48 period (i.e., 2003-2005). In Panel C, Column (1) reports the regression results for the difference-in-differences quasi-natural experiment design. In the natural experiment, the treatment firms are defined as those that disclose positive UTB in any of the three years after FIN48, and the control firms are those that do not undertake any uncertain tax position in both pre- and post-FIN48 periods. The sample used for the natural experiment covers the years of 2003-2005 before FIN48 and of 2007-2009 after FIN48. Column (2) reports the OLS regression results for the test of H1 using UTB as an alternative measure of corporate tax avoidance. The sample period covers the years 20072014. The industry dummies, constructed based on the Fama-French's twelve industries, are included in the DiD regression; year dummies are included in both regressions; all these dummies are not reported for brevity. The variables are all defined in the appendix. The $p$ values in brackets are based on robust standard errors clustered by firm and year

The results highlighted in bold are those for the key independent variables of our regressions ***, **, *represent the 1,5 , and 10\% statistical significance levels (two-tailed), respectively

All in all, based on our empirical analyses, we conclude that analysts are less likely to follow firms that engage more in corporate tax avoidance activities. One reason for the mixed prior evidence on the relation between corporate tax avoidance and earnings management is the endogeneity problem which is not satisfactorily resolved in the literature to date. Corporate tax avoidance and earnings management are both driven by managerial incentives, and hence are particularly susceptible to endogeneity. When applying a two-stage-least-squares regression model to address any such endogeneity, it is difficult to identify a valid instrumental variable which influences tax avoidance but does not have a direct impact on earnings management. Identification of exogenous shocks with which to conduct a natural experiment does not work in addressing 
this issue. This is because the time-series vis-à-vis cross-section relations between tax avoidance and earnings management, as we argue previously, run in the opposite direction and thus cannot be disentangled via a natural experiment. Analyst coverage provides a nice setting to help shed light on this issue, since analysts use the time-series record of earnings information to make their forecasts. From the negative impact of corporate tax avoidance on analyst coverage, we draw the inference that tax avoidance is likely associated with earnings management in the time-series.

\section{Additional tests}

In this section, we explore a number of other issues relating to the impact of corporate tax avoidance on analyst behavior. First, we test whether our main results might be related to tax risk issues, and then the extent to which corporate tax avoidance affects analyst earnings forecast informativeness and forecast errors.

\subsection{The effect of tax risk on analyst coverage}

In this first sub-section, we investigate the impact of corporate tax risk on analyst coverage. Tax risk is conceptually different from tax avoidance, in that the former refers to the volatility of a firm's tax positions across years while the latter refers to the level of a firm's tax position in a particular year (e.g. Guenther et al. 2017; Wilde and Wilson 2018; Drake et al. 2019). As argued in Sect. 2.2, in attempting to deflect unwanted attention and scrutiny from outsiders, firms are unlikely to seek to avoid taxes either in consecutive years or concurrently with earnings management. More likely, volatile annual tax positions reflect a firm's strategic tax planning. It is thus important to also explore whether tax risk affects analyst coverage. Tax risk is conventionally defined as the volatility of a firm's tax position over time (e.g. Drake et al. 2019). Accordingly, we measure tax risk by the volatility in income tax payments, calculated as the standard deviation of annual effective tax rates over the past five-year period (stdetr). Our tax risk (stdetr) measure should be able to capture any inter-temporal, non-consecutive tax avoidance strategy. We expect that firms adopting such a strategy would have higher tax risk, and as a result, are less likely to attract analyst following. To test this conjecture, we formulate the following regression model using both OLS and firm-fixed-effects specifications:

$$
\text { lanacov }_{i, t}=\alpha_{0}+\alpha_{1} \text { stdetr }_{i, t}+\sum_{k} \alpha_{i, k} \text { controls }_{i}^{k}+\text { YearDummies }+\varepsilon_{i, t}
$$

We include the same set of control variables as in model (2). Table 5 presents the regression results. As can be seen, the coefficients on stdetr are negative and statistically significant in both the OLS and firm-fixed-effects regressions. This is in line with our prediction that analysts are less likely to follow firms that exhibit high tax risk. In Column (1) (Column (2)), a one-standard-deviation increase in stdetr is associated with a decrease in lanacov of 0.5329 (0.5133), which accounts for $22.32 \%(21.50 \%)$ of the sample mean of lanacov and is thus economically significant.

\subsection{The effect of corporate tax avoidance on the informativeness of analyst forecasts}

This sub-section explores whether corporate tax avoidance affects the informativeness of analyst earnings forecasts. We follow Frankel et al. (2006) to define analyst earnings 
Table 5 Additional test: The impact of tax risk on analyst coverage

\begin{tabular}{|c|c|c|}
\hline \multirow[t]{2}{*}{ Variables } & \multicolumn{2}{|c|}{ Dependent variable $=$ lanacov } \\
\hline & (1) OLS & (2) Firm-fixed-effects \\
\hline \multirow[t]{2}{*}{ stdetr } & $-0.3285^{* * *}$ & $-0.3164 * * *$ \\
\hline & $(<0.001)$ & $(0.006)$ \\
\hline \multirow[t]{2}{*}{ size } & $0.5218 * * *$ & $0.3816^{* * *}$ \\
\hline & $(<0.001)$ & $(<0.001)$ \\
\hline \multirow[t]{2}{*}{ tradingvol } & $-1.23 \mathrm{E}-10^{* *}$ & $-1.65 \mathrm{E}-10 * * *$ \\
\hline & $(0.026)$ & $(0.007)$ \\
\hline \multirow[t]{2}{*}{ beta } & $0.5137 * * *$ & $0.1260 * * *$ \\
\hline & $(<0.001)$ & $(<0.001)$ \\
\hline \multirow[t]{2}{*}{ retvol } & 1.3103 & $1.5977^{*}$ \\
\hline & $(0.231)$ & $(0.074)$ \\
\hline \multirow[t]{2}{*}{ stdeps } & $-0.0002 * * *$ & $-0.0002^{* * *}$ \\
\hline & $(<0.001)$ & $(<0.001)$ \\
\hline \multirow[t]{2}{*}{ price } & $-0.0001 * * *$ & $7.33 \mathrm{E}-06$ \\
\hline & $(<0.001)$ & $(0.314)$ \\
\hline \multirow[t]{2}{*}{ qtrret } & $-0.1839 * * *$ & $-0.1578^{* * *}$ \\
\hline & $(<0.001)$ & $(<0.001)$ \\
\hline \multirow[t]{2}{*}{ roa } & $-0.3776^{* * *}$ & $-0.3265^{* * *}$ \\
\hline & $(<0.001)$ & $(<0.001)$ \\
\hline \multirow[t]{2}{*}{$h p$} & $-1.14 \mathrm{E}-05$ & $-9.37 \mathrm{E}-05^{* * *}$ \\
\hline & $(0.297)$ & $(<0.001)$ \\
\hline \multirow[t]{2}{*}{ insti } & 0.0702 & 0.0143 \\
\hline & $(0.467)$ & $(0.280)$ \\
\hline \multirow[t]{2}{*}{$r d$} & $-0.2845^{* * *}$ & 0.0335 \\
\hline & $(<0.001)$ & $(0.422)$ \\
\hline \multirow[t]{2}{*}{ intangible } & 0.0395 & 0.1090 \\
\hline & $(0.541)$ & $(0.126)$ \\
\hline \multirow[t]{2}{*}{ btm } & 0.0028 & $0.0245^{* *}$ \\
\hline & $(0.319)$ & $(0.015)$ \\
\hline \multirow[t]{2}{*}{$f d$} & -0.8429 & $0.3882 * * *$ \\
\hline & $(0.246)$ & $(<0.001)$ \\
\hline \multirow[t]{2}{*}{ regulated } & $-0.3047 * * *$ & \\
\hline & $(<0.001)$ & \\
\hline Adjusted $\mathrm{R}^{2}$ & 0.5783 & 0.2286 \\
\hline Observations & 23,362 & 23,362 \\
\hline
\end{tabular}

This table reports the results for the tests of the impact of tax risk on analyst coverage. Column (1) ((2)) reports the results from the OLS (firmfixed-effects) regressions. The sample spans the period of 1995-2014. The dependent variable is analyst coverage, namely, lanacov. The treatment variable is tax risk, namely, stdetr. All the variables are defined in the Appendix. The firm-fixed-effects regression automatically drops independent variables that exhibit no within-firm variance, and thus regulated is omitted for the firm-fixed-effects regression results. Year dummies are included in both regressions but not reported for brevity. The $p$ values in brackets are based on robust standard errors that are clustered by firm and year (firm) in the OLS (firmfixed-effects) regressions

The results highlighted in bold are those for the key independent variables of our regressions

***,**, *represent the 1,5 , and $10 \%$ statistical significance levels (two-tailed), respectively 
forecast informativeness as the extent to which stock prices react to analyst earnings forecasts. Corporate tax avoidance will impact the informativeness of analyst forecasts under two conditions: first, investors are able to observe corporate tax avoidance on a timely basis and to comprehend its adverse influence on corporate financial transparency; second, analysts are perceived by investors to be more capable of deciphering the implications of corporate tax avoidance for future earnings, thus rendering analyst forecasts more informative to investors. If both assumptions hold, we would expect investors to react more strongly to analyst earnings forecasts in the case of perceived corporate tax aggressiveness. On the other hand, if either assumption does not hold, corporate tax avoidance should not impact analyst forecast informativeness. To test this proposition, we run both OLS and firm-fixed-effects regressions for the following model:

$$
\operatorname{car}_{i, t}=\alpha_{0}+\alpha_{1} \operatorname{lretr}_{i, t}\left(\operatorname{ddmpbtd}_{i, t}\right)+\sum_{k} \alpha_{i, k} \operatorname{controls}_{i}^{k}+\text { YearDummies }+\varepsilon_{i, t}
$$

where car equals the cumulative unsigned abnormal stock returns over the three-day window $[-1,1]$ centered on the announcement date of an analyst's last forecast of annual EPS for the fiscal year. If multiple analysts make EPS forecasts for the same firm, car is taken as the average of the abnormal returns associated with these forecasts. The market reaction to analyst earnings forecasts reflects investor demand for such forecasts. Hence, in line with prior research (e.g. Frankel et al. 2006; Arand et al. 2015), we control for a range of determinants of the demand for analyst forecasts: firm size (size), trading volume (tradingvol), firm beta (beta), return volatility (retvol), earnings volatility (stdeps), stock price (price), abnormal stock returns (qtrret), pre-tax return on assets (roa), financial constraints $(h p)$, institutional ownership (insti), research and development expenditures $(r d)$, intangible assets (intangible), book-to-market ratio $(\mathrm{btm})$, post-FD-period indicator $(\mathrm{fd})$, industrial regulatory status (regulated). All these control variables are defined in the Appendix.

Columns (1-2) ((3-4)) of Table 6 present the OLS (firm-fixed-effects) regression results from running Eq. (5). None of the coefficients for lretr and ddmpbtd is statistically significant, which is inconsistent with corporate tax avoidance being associated with analyst forecast informativeness.

In general, investors do not have access to private information, making it difficult for them to promptly observe tax avoidance activities that occur sporadically. Even if investors do manage to recognize tax avoidance, they may not understand its adverse impact on financial transparency, and thus not resort to increased analyst services. Furthermore, analysts might not always be able to infer the implications of tax avoidance for future earnings. All such factors could potentially help explain why corporate tax avoidance does not appear to be associated with an increase in the stock market reactions to analyst forecasts. Importantly, in contrast to our earlier evidence which is consistent with the supply-curve argument of our main hypothesis, the insignificant results for model (5) confute the alternative analyst- demand-curve argument which posits that corporate tax avoidance raises investor demand for analyst forecasts and increases analyst coverage.

\subsection{The effect of corporate tax avoidance on analyst forecast errors}

Corporate tax avoidance obfuscates financial information and makes accurate forecasting more difficult for analysts. As such, it is plausible that corporate tax avoidance activities increase analyst forecast errors. In this sub-section, we examine whether conditional on analysts following a firm, corporate tax avoidance impacts analyst forecast errors. Since 
Table 6 Additional test: The impact of corporate tax avoidance on the informativeness of analyst earnings forecasts

\begin{tabular}{|c|c|c|c|c|}
\hline \multirow[t]{3}{*}{ Variables } & \multicolumn{4}{|c|}{ Dependent variable $=$ car } \\
\hline & \multicolumn{2}{|l|}{$\overline{\text { OLS }}$} & \multicolumn{2}{|c|}{ Firm-fixed-effects } \\
\hline & (1) & (2) & (3) & (4) \\
\hline \multirow[t]{2}{*}{ lretr } & 0.0033 & & 0.0027 & \\
\hline & $(0.237)$ & & $(0.534)$ & \\
\hline \multirow[t]{2}{*}{ ddmpbtd } & & $-3.76 \mathrm{E}-05$ & & $1.12 E-04$ \\
\hline & & $(0.843)$ & & $(0.348)$ \\
\hline \multirow[t]{2}{*}{ size } & $0.0017 * * *$ & $-4.53 \mathrm{E}-06$ & -0.0016 & $-0.0042 * * *$ \\
\hline & $(<0.001)$ & $(0.993)$ & $(0.215)$ & $(<0.001)$ \\
\hline \multirow[t]{2}{*}{ tradingvol } & $-3.68 \mathrm{E}-06^{* *}$ & 7.14E-08 & $-8.28 \mathrm{E}-06^{* *}$ & $-3.67 \mathrm{E}-06$ \\
\hline & $(0.022)$ & $(0.959)$ & $(0.045)$ & $(0.533)$ \\
\hline \multirow[t]{2}{*}{ beta } & $-0.0035^{* * *}$ & 0.0020 & $-0.0055^{* * *}$ & $4.86 \mathrm{E}-05$ \\
\hline & $(<0.001)$ & $(0.132)$ & $(<0.001)$ & $(0.977)$ \\
\hline \multirow[t]{2}{*}{ retvol } & $2.4821 * * *$ & $2.0208^{* * *} *$ & $2.3625^{* * *} *$ & $1.7774 * * *$ \\
\hline & $(<0.001)$ & $(<0.001)$ & $(<0.001)$ & $(<0.001)$ \\
\hline \multirow[t]{2}{*}{ stdeps } & $4.30 \mathrm{E}-06^{* *}$ & $-1.23 \mathrm{E}-07 * * *$ & $2.10 \mathrm{E}-05$ & $-6.49 \mathrm{E}-08$ \\
\hline & $(0.014)$ & $(<0.001)$ & $(0.471)$ & $(0.003)$ \\
\hline \multirow[t]{2}{*}{ price } & $-2.12 \mathrm{E}-05^{* *}$ & $-3.66 \mathrm{E}-05^{* * *}$ & $-1.42 \mathrm{E}-05$ & $-3.50 \mathrm{E}-05^{* *}$ \\
\hline & $(0.012)$ & $(<0.001)$ & $(0.491)$ & $(0.047)$ \\
\hline \multirow[t]{2}{*}{ qtrret } & $-0.0047 * * *$ & $-0.0039 * * *$ & $-0.0054^{* * * *}$ & $-0.0034 * * *$ \\
\hline & $(<0.001)$ & $(<0.001)$ & $(<0.001)$ & $(0.002)$ \\
\hline \multirow[t]{2}{*}{ roa } & 0.0021 & 0.0027 & 0.0001 & 0.0014 \\
\hline & $(0.644)$ & $(0.371)$ & $(0.987)$ & $(0.740)$ \\
\hline \multirow[t]{2}{*}{$h p$} & $5.00 \mathrm{E}-06 * * *$ & $4.44 \mathrm{E}-06 * * *$ & $-1.42 \mathrm{E}-06$ & $-2.85 \mathrm{E}-06^{* * *}$ \\
\hline & $(<0.001)$ & $(<0.001)$ & $(0.194)$ & $(0.005)$ \\
\hline \multirow[t]{2}{*}{ insti } & $0.0096^{* * *}$ & $0.0089 * * *$ & $0.0071 * * *$ & $0.0071 * * *$ \\
\hline & $(<0.001)$ & $(<0.001)$ & $(0.007)$ & $(0.003)$ \\
\hline \multirow[t]{2}{*}{$r d$} & -0.0002 & 0.0001 & -0.0016 & 0.0008 \\
\hline & $(0.891)$ & $(0.948)$ & $(0.482)$ & $(0.693)$ \\
\hline \multirow[t]{2}{*}{ intangible } & $0.0024^{* * * *}$ & $0.0012 * * *$ & -0.0010 & -0.0005 \\
\hline & $(0.010)$ & $(0.006)$ & $(0.298)$ & $(0.181)$ \\
\hline \multirow[t]{2}{*}{ btm } & $-1.26 \mathrm{E}-05^{* * *}$ & $-4.89 \mathrm{E}-06 * * *$ & $2.08 \mathrm{E}-05$ & $4.75 \mathrm{E}-04^{*}$ \\
\hline & $(<0.001)$ & $(0.007)$ & $(0.945)$ & $(0.054)$ \\
\hline \multirow[t]{2}{*}{$f d$} & $0.0162 * * *$ & $0.0124 * * *$ & $0.0072 * *$ & 0.0002 \\
\hline & $(<0.001)$ & $(<0.001)$ & $(0.045)$ & $(0.947)$ \\
\hline \multirow[t]{2}{*}{ regulated } & $-0.0066^{* * * *}$ & $-0.0103 * * *$ & & \\
\hline & $(<0.001)$ & $(<0.001)$ & & \\
\hline Adjusted $\mathrm{R}^{2}$ & 0.4488 & 0.4603 & 0.3095 & 0.2696 \\
\hline Observations & 16,783 & 23,563 & 16,783 & 23,563 \\
\hline
\end{tabular}

This table presents the results for the tests of the impact of corporate tax avoidance on the informativeness of analyst earnings forecasts. Columns (1-2) ((3-4)) reports the results from the OLS (firm-fixed-effects) regressions. The sample spans the period of 1995-2014. The dependent variable is the cumulative unsigned abnormal stock returns, namely, car. The treatment variable is corporate tax avoidance which are proxied by the long-run cash effective tax rate (lretr) and residual domestic book-tax difference (ddmpbtd). The firm-fixed-effects regression automatically drops any independent variable that exhibits no within-firm variance, and thus regulated is omitted for the firm-fixed-effects regression results. All the variables are defined in the Appendix. Year dummies are included in all the regressions but not reported for simplicity. The $p$ 
Table 6 (continued)

values in brackets are based on robust standard errors that are clustered by firm and year (firm) in the OLS (firm-fixed-effects) regressions

The results highlighted in bold are those for the key independent variables of our regressions $* * *, * *$, *represent the 1,5 , and $10 \%$ statistical significance levels (two-tailed), respectively

analyst compensation is tied to investor demand for analyst services, analysts have incentives to maintain a good reputation with investors. Due to the reputation concern, analysts often opt to cover a firm for which they feel confident in making accurate forecasts (Das et al. 2006; Franco et al. 2015), and thus may refrain from covering a tax-avoiding firm that is perceived as having high financial opacity. If, on the other hand, they still decide to cover such firms, they might be prepared to incur the necessary greater information acquisition and/or processing costs required to maintain forecast accuracy. ${ }^{6}$ In such cases, corporate tax avoidance will not increase analyst forecast errors. To test this proposition, we run both OLS and firm-fixed-effects regressions for the following model:

$$
\text { error }_{i, t}=\alpha_{0}+\alpha_{1} \text { lretr }_{i, t}\left(\text { ddmpbtd }_{i, t}\right)+\sum_{k} \alpha_{i, k} \text { controls }_{i}^{k}+\text { YearDummies }+\varepsilon_{i, t}
$$

where error equals the absolute difference between actual EPS per I/B/E/S and an analyst's last forecast of annual EPS for a firm for a fiscal year, divided by the firm's stock price at the end of the fiscal year. ${ }^{7}$ If there are multiple analysts making the EPS forecasts for a firm, we employ the average of their last available forecasts for annual EPS. In line with prior research on analyst forecast errors (Lang and Lundholm 1996; Das et al. 1998; Lim 2001; Hong and Kubik 2003; Ke and Yu 2006; Dhaliwal et al. 2012; Hao et al. 2017; Bhandari et al. 2018), we control for firm size (size), return volatility (retvol), stock price (price), abnormal stock returns (qtrret), pre-tax return on assets (roa), financial constraints ( $h p$ ), institutional ownership (insti), intangible assets (intangible), book-to-market ratio (btm), analyst forecast horizon (horizon), abnormal trading volume (abtradvol), change in pre-tax return on assets (changeroa), and change in EPS (changeeps). These variables are defined in the Appendix. Columns (1-2) ((3-4)) of Table 7 report the OLS (firm-fixed-effects) regression results. The coefficients on $\operatorname{lretr}(d d m p b t d)$ are not statistically significant. Thus, there is no evidence indicating that corporate tax avoidance leads to increased analyst forecast errors. On this basis, conditional on deciding to follow a tax-aggressive firm, analysts appear prepared to invest the necessary additional efforts and resources to maintain their forecast accuracy.

\section{Conclusion}

We extend the tax avoidance literature by investigating whether and how corporate tax avoidance affects analyst coverage and forecasts. Despite the extensive tax research to date, the informational role of corporate tax avoidance in capital markets

\footnotetext{
6 This argument is in line with Bratten et al. (2017) who find that as corporate tax complexity increases, tax-expert analysts are more accurate in their forecasts relative to management forecasts.

${ }^{7}$ Our results remain qualitatively the same, if we use the earnings from Compustat (which are adjusted for transitory components of earnings) instead of from I/B/E/S to construct our analyst forecast error variable in our regression analysis. We also obtain similar results and inferences if we repeat our regression analysis by looking at positive and negative analyst forecast errors separately. A positive (negative) analyst forecast error is defined as the absolute difference between actual EPS and an analyst's last forecast of annual EPS for a firm for a fiscal year, divided by the firm's stock price at the end of the fiscal year, if actual EPS is higher (lower) than the analyst forecast of annual EPS, and 0 if actual EPS is lower (higher) than the analyst's last forecast of annual EPS.
} 
Table 7 Additional test: The impact of corporate tax avoidance on analyst forecast errors

\begin{tabular}{|c|c|c|c|c|}
\hline \multirow[t]{3}{*}{ Variables } & \multicolumn{4}{|c|}{ Dependent variable $=$ error } \\
\hline & \multicolumn{2}{|l|}{ OLS } & \multicolumn{2}{|c|}{ Firm-fixed-effects } \\
\hline & (1) & (2) & (3) & (4) \\
\hline lretr & $\begin{array}{l}-0.0424 \\
(0.189)\end{array}$ & & $\begin{array}{l}0.0352 \\
(0.208)\end{array}$ & \\
\hline ddmpbtd & & $\begin{array}{l}0.0044 \\
(0.236)\end{array}$ & & $\begin{array}{l}0.0022 \\
(0.479)\end{array}$ \\
\hline size & $\begin{array}{l}-0.0026 \\
(0.641)\end{array}$ & $\begin{array}{l}-0.0174 * * * \\
(0.003)\end{array}$ & $\begin{array}{l}-0.0446^{* * * *} \\
(0.009)\end{array}$ & $\begin{array}{l}-0.0717 * * * \\
(<0.001)\end{array}$ \\
\hline retvol & $\begin{array}{l}3.3065 * * * \\
(<0.001)\end{array}$ & $\begin{array}{l}3.5370 * * * \\
(<0.001)\end{array}$ & $\begin{array}{l}2.2022 * * * \\
(0.002)\end{array}$ & $\begin{array}{l}3.0490 * * * \\
(<0.001)\end{array}$ \\
\hline price & $\begin{array}{l}0.0005^{* * *} \\
(<0.001)\end{array}$ & $\begin{array}{l}0.0009 * * * \\
(<0.001)\end{array}$ & $\begin{array}{l}0.0012 * * * \\
(<0.001)\end{array}$ & $\begin{array}{l}0.0020 * * * \\
(<0.001)\end{array}$ \\
\hline qtrret & $\begin{array}{l}-0.0139 * * * \\
(0.005)\end{array}$ & $\begin{array}{l}-0.0155^{* * * *} \\
(<0.001)\end{array}$ & $\begin{array}{l}-0.0029 \\
(0.638)\end{array}$ & $\begin{array}{l}-0.0035 \\
(0.424)\end{array}$ \\
\hline roa & $\begin{array}{l}-0.4608 * * * \\
(<0.001)\end{array}$ & $\begin{array}{l}-0.5465 * * * \\
(<0.001)\end{array}$ & $\begin{array}{l}-0.3315^{* * * *} \\
(<0.001)\end{array}$ & $\begin{array}{l}-0.3620 * * * \\
(<0.001)\end{array}$ \\
\hline$h p$ & $\begin{array}{l}-1.43 \mathrm{E}-05^{* *} \\
(0.043)\end{array}$ & $\begin{array}{l}-3.63 \mathrm{E}-05 * * * \\
(<0.001)\end{array}$ & $\begin{array}{l}-1.56 \mathrm{E}-05 \\
(0.116)\end{array}$ & $\begin{array}{l}-2.40 \mathrm{E}-05^{* *} \\
(0.024)\end{array}$ \\
\hline insti & $\begin{array}{l}-0.0846^{* * * *} \\
(<0.001)\end{array}$ & $\begin{array}{l}-0.1670 * * * \\
(<0.001)\end{array}$ & $\begin{array}{l}-0.0053 \\
(0.630)\end{array}$ & $\begin{array}{l}-0.0283^{*} \\
(0.094)\end{array}$ \\
\hline intangible & $\begin{array}{l}0.0296 \\
(0.307)\end{array}$ & $\begin{array}{l}0.0034 \\
(0.730)\end{array}$ & $\begin{array}{l}-0.0087 \\
(0.409)\end{array}$ & $\begin{array}{l}0.0045 \\
(0.315)\end{array}$ \\
\hline btm & $\begin{array}{l}0.1108 * * * \\
(<0.001)\end{array}$ & $\begin{array}{l}0.1480 * * * \\
(<0.001)\end{array}$ & $\begin{array}{l}0.1114 * * * \\
(<0.001)\end{array}$ & $\begin{array}{l}0.1333 * * * \\
(<0.001)\end{array}$ \\
\hline horizon & $\begin{array}{l}0.0006^{* * * *} \\
(<0.001)\end{array}$ & $\begin{array}{l}0.0010 * * * \\
(<0.001)\end{array}$ & $\begin{array}{l}0.0005 * * * \\
(<0.001)\end{array}$ & $\begin{array}{l}0.0009 * * * \\
(<0.001)\end{array}$ \\
\hline abtradvol & $\begin{array}{l}1.42 \mathrm{E}-06 \\
(0.951)\end{array}$ & $\begin{array}{l}3.61 \mathrm{E}-05 \\
(0.426)\end{array}$ & $\begin{array}{l}-6.23 \mathrm{E}-06 \\
(0.524)\end{array}$ & $\begin{array}{l}1.83 \mathrm{E}-06 \\
(0.937)\end{array}$ \\
\hline changeroa & $\begin{array}{l}8.47 \mathrm{E}-06^{* * *} \\
(<0.001)\end{array}$ & $\begin{array}{l}1.05 \mathrm{E}-05^{* * *} \\
(<0.001)\end{array}$ & $\begin{array}{l}0.0041 \\
(0.329)\end{array}$ & $\begin{array}{l}2.71 \mathrm{E}-05^{* * * *} \\
(<0.001)\end{array}$ \\
\hline changeeps & $\begin{array}{l}-0.0224 * * * \\
(<0.001)\end{array}$ & $\begin{array}{l}-4.10 \mathrm{E}-06 \\
(0.297)\end{array}$ & $\begin{array}{l}-0.0185^{* * * *} \\
(<0.001)\end{array}$ & $\begin{array}{l}6.59 \mathrm{E}-06^{* * * *} \\
(<0.001)\end{array}$ \\
\hline Adjusted $\mathrm{R}^{2}$ & 0.1794 & 0.2055 & 0.2056 & 0.1981 \\
\hline Observations & 14,096 & 21,040 & 14,096 & 21,040 \\
\hline
\end{tabular}

This table presents the results for the tests of the impact of corporate tax avoidance on analyst earnings forecast errors. Columns (1-2) ((3-4)) reports the results from the OLS (firm-fixed-effects) regressions. The sample spans the period of 1995-2014. The dependent variable is analyst forecast errors, namely, error. The treatment variable is corporate tax avoidance which are proxied by the long-run cash effective tax rate (lretr) and residual domestic book-tax difference (ddmpbtd). All the variables are defined in the Appendix. Year dummies are included in all the regressions but not reported for simplicity. The $p$ values in brackets are based on robust standard errors that are clustered by firm and year (firm) in the OLS (firm-fixed-effects) regressions

The results highlighted in bold are those for the key independent variables of our regressions $* * *, * *$, *represent the 1,5 , and $10 \%$ statistical significance levels (two-tailed), respectively 
remains an underexplored area. Our study fills this gap in the literature. In developing our testable hypothesis, we first seek to reconcile the mixed prior evidence on the relationship between corporate tax avoidance and earnings management. To this end, we argue that the association between tax avoidance and earnings management is contemporaneously negative, but that the lead-lag association between the two is positive, such that overall, high corporate tax avoidance is associated with a high level of earnings management in the time-series. Moreover, tax avoidance itself makes financial information opaque (e.g. Graham and Tucker 2006; Kim et al. 2011). Thus, corporate tax avoidance transactions obfuscate the trend record of financial information used by analysts for their forecasts. Given the high opacity resulting from tax avoidance activities, analysts have to incur high information gathering and/or processing costs for their earnings forecasts, and are at high risks of issuing inaccurate forecasts and of reputational losses; this reduces the net benefits to analysts of providing earnings forecasts. Therefore, we expect analysts to be less likely to cover firms with a high level of tax avoidance activities. Our results support this conjecture and are robust to the use of a firm-fixed-effects model and of a quasinatural experiment to control for potential endogeneity.

In additional analyses, we predict and show that firms implementing riskier taxplanning strategies tend to have lower analyst following. However, we do not find evidence that given an analyst's decision to follow a tax-avoiding firm, the market reaction to her/his earnings forecasts increases, which is inconsistent with the "demand-curve" argument that corporate tax avoidance will raise demand for analyst services. We also find no evidence that conditional on an analyst's decision to cover a firm engaged in tax avoidance, forecast errors increase as a result; this we attribute to greater analyst effort. Overall, our results add to the negative consequences of corporate tax avoidance: it reduces analyst following, potentially undermining the analysts' overall information intermediary role in capital markets, and might thereby weaken market efficiency. Thus, our study should be relevant to regulators and authorities, who are charged with improving the corporate taxation environments and, more generally, disclosure transparency in the financial marketplace. As suggested by Kuo and Lee (2016), regulators and tax authorities may enforce an increase in book-tax conformity to reduce the likelihood and extent of tax avoidance, or earnings management, by managers.

Acknowledgements We appreciate the helpful comments of Cheng-Few Lee (the editor), an anonymous reviewer, Paul Mason, Mark Bradshaw, Martin Jacob, Daniele Bianchi, Michael Moore, Onur Tosun, and participants at the 2016 American Accounting Association annual meeting, 2016 Annual Congress of the European Accounting Association, and a Finance Group seminar at Warwick Business School. All errors are our own.

Open Access This article is distributed under the terms of the Creative Commons Attribution 4.0 International License (http://creativecommons.org/licenses/by/4.0/), which permits unrestricted use, distribution, and reproduction in any medium, provided you give appropriate credit to the original author(s) and the source, provide a link to the Creative Commons license, and indicate if changes were made.

\section{Appendix}

See Table 8 . 
Table 8 Summary of variable definitions

\begin{tabular}{|c|c|}
\hline Variables & Definitions \\
\hline nacov & $\begin{array}{l}\text { The natural logarithm of } 1 \text { plus the number of analysts that make at least one annual EPS } \\
\text { forecast for a firm over a fiscal year. lanacov equals } 0 \text { if there is no analyst forecasting annual } \\
\text { EPS for a firm over a fiscal year }\end{array}$ \\
\hline error & $\begin{array}{l}\text { The absolute value of the difference between actual EPS and an analyst's last forecast of annual } \\
\text { EPS for a firm for a fiscal year, divided by the firm's stock price at the end of the fiscal year. } \\
\text { If there are multiple analysts forecasting annual EPS for a firm for a fiscal year, the average } \\
\text { is taken of the analysts' last forecasts of annual EPS. error is winsorized at the } 1 \% \text { and } 99 \% \\
\text { levels, respectively }\end{array}$ \\
\hline car & $\begin{array}{l}\text { Three-day }[-1,1] \text { cumulative unsigned abnormal stock returns surrounding an analyst's last } \\
\text { forecast of EPS for a fiscal year. The abnormal stocks returns are calculated using market } \\
\text { model with an estimation period of }[-181,-2] \text { relative to the forecast date. If there are } \\
\text { multiple analysts forecasting EPS for a firm for a fiscal year, the average is taken of the cumu- } \\
\text { lative unsigned abnormal stock returns }\end{array}$ \\
\hline lretr & $\begin{array}{l}\text { Long-run cash effective tax rate based on Dyreng et al. (2008), which is computed as the sum } \\
\text { of corporate income tax paid, divided by the sum of a firm's pre-tax income net of special } \\
\text { items, over the previous five years. Consistent with prior literature, LRETR is truncated to fall } \\
\text { within the interval }[0,1]\end{array}$ \\
\hline ddmpbtd & $\begin{array}{l}\text { The residual domestic book-tax difference based on Desai and Dharmapala (2006), } \\
\text { which equals the residuals from the following firm-fixed-effects regression model: } \\
m p b t d_{\mathrm{i}, \mathrm{t}}=\beta_{1} t a_{\mathrm{i}, \mathrm{t}}+\mathrm{u}_{\mathrm{i}}+\varepsilon_{\mathrm{i}, \mathrm{t}} m p b t d \text { is domestic book-tax difference based on Manzon-Plesko } \\
(2002) \text {, which is calculated as: (domestic pre- tax income-(current federal income tax } \\
\text { expense/statutory tax rate)—-state income tax expense-other income tax expense-equity } \\
\text { income)/lagged total assets. TA is total accruals measured using the cash flow method of } \\
\text { Hribar and Collins (2002). Both } M P B T D \text { and } T A \text { are scaled by lagged total assets and win- } \\
\text { sorized at the } 1 \% \text { and } 99 \% \text { levels for the fixed effect regression estimation }\end{array}$ \\
\hline stdetr & The standard deviation of annual GAAP effective tax rates over the period of year $t-4$ to $t$ \\
\hline$u t b$ & The natural logarithm of 1 plus a firm's uncertain tax benefits at the end of a fiscal year \\
\hline yutb & $\begin{array}{l}1 \text { if a firm is in a three-year period (i.e., 2007-2009) after the implementation of FIN48 and } 0 \\
\text { if a firm is in a three-year period (i.e., 2003-2005) before the passage of FIN48 }\end{array}$ \\
\hline tutb & 1 if a firm discloses a positive amount of uncertain tax benefits for a fiscal year and 0 otherwise \\
\hline tradingvol & Dollar trading volumes over a fiscal year for a firm \\
\hline fd & $\begin{array}{l}1 \text { for the post-FD period (i.e., years of 2001-2014), and } 0 \text { for the pre-FD period (i.e., years of } \\
1995-2000 \text { ) }\end{array}$ \\
\hline beta & Equity beta for a firm for a fiscal year \\
\hline stdeps & The standard deviation of annual EPS over the period of year $t-4$ to $t$ \\
\hline retvol & The standard deviation of daily market excess returns over a fiscal year \\
\hline price & Stock price of a firm at the fiscal year end date \\
\hline size & The natural logarithm of the market value of a firm's equity at the end of a fiscal year \\
\hline$b t m$ & $\begin{array}{l}\text { The book value of firm equity divided by the market value of firm equity at the end of a fiscal } \\
\text { year }\end{array}$ \\
\hline insti & $\begin{array}{l}\text { Institutional investors' stock ownership as a percentage of the outstanding shares for a firm at } \\
\text { the end of a fiscal year }\end{array}$ \\
\hline$r d$ & 1 if research and development expense of a firm is positive for a fiscal year and 0 otherwise \\
\hline qtrret & Buy-and-hold abnormal stock returns of a firm for a fiscal year \\
\hline intangible & Intangible assets divided by total assets for a firm at the end of a fiscal year \\
\hline roa & Pre-tax income net of special items and divided by total assets at the end of a fiscal year \\
\hline$h p$ & $\begin{array}{l}\text { A financial constraint index }(h p) \text { developed by Hadlock and Pierce }(2010) . H p=-0.737 * \text { size } \\
+0.043 * \text { size } e^{2}-0.040 * \text { age, where size is the natural logarithm of total assets capped at } \$ 4.5 \\
\text { billion, and age is the number of years a firm has been listed }\end{array}$ \\
\hline
\end{tabular}


Table 8 (continued)

\begin{tabular}{|c|c|}
\hline Variables & Definitions \\
\hline regulated & $\begin{array}{l}1 \text { if a firm belongs to a regulated industry (SIC 4900-4999, 6000-6411, or 6500-6999) and } 0 \\
\text { otherwise }\end{array}$ \\
\hline equityic & Equity income in earnings, scaled by lagged total assets \\
\hline foreignic & Foreign income scaled by lagged total assets \\
\hline firmage & $\begin{array}{l}\text { The number of months since a firm's IPO. If the IPO date is not available in Compustat, the } \\
\text { firm age variable represents the number of months since CRSP first reported return data for } \\
\text { the firm }\end{array}$ \\
\hline$l e v$ & Long-term debt scaled by lagged total assets \\
\hline ppe & Property, plant, and equipment scaled by lagged total assets \\
\hline horizon & $\begin{array}{l}\text { The natural log of the number of days between an analyst's last annual EPS forecast date and a } \\
\text { firm's earnings announcement date. If there are multiple analysts that forecast annual EPS for } \\
\text { a firm for a fiscal year, the average is taken of the number of days between analysts' last EPS } \\
\text { forecast dates and a firm's earnings announcement date }\end{array}$ \\
\hline abtradvol & $\begin{array}{l}\text { Abnormal trading volume of a firm for a fiscal year, which is computed as dollar trading vol- } \\
\text { ume over the last two fiscal quarters of a year minus dollar trading volume over the first two } \\
\text { fiscal quarters }\end{array}$ \\
\hline changeroa & $\begin{array}{l}\text { Return on assets of a firm for the current fiscal year minus that for the previous fiscal year. } \\
\text { Return on assets is computed as pre-tax income net of special items and divided by total } \\
\text { assets at the end of a fiscal year }\end{array}$ \\
\hline changeeps & $\begin{array}{l}\text { Annual EPS of a firm for the current fiscal year minus that for the previous year, divided by } \\
\text { stock price at the end of the previous fiscal year }\end{array}$ \\
\hline
\end{tabular}

\section{References}

Abarbanell J, Lehavy R (2003) Biased forecasts or biased earnings? The role of reported earnings in explaining apparent bias and over/underreaction in analysts' earnings forecasts. J Account Econ 36:105-146

Aboody D, Lev B (2000) Information asymmetry, R\&D, and insider gains. J Finance 55:2747-2766

Aggarwal R, Mishra D, Wilson C (2018) Analyst recommendations and the implied cost of equity. Rev Quant Financ Account 50:717-743

Ajinkya B, Bhojraj S, Sengupta P (2005) The association between outside directors, institutional investors and the properties of management earnings forecasts. J Account Res 43:343-376

Allen A, Francis BB, Wu Q, Zhao Y (2016) Analyst coverage and corporate tax aggressiveness. J Bank Finance 72:84-98

Arand D, Kerl A, Walter A (2015) When do sell-side analyst reports really matter? Shareholder protection, institutional investors and the informativeness of equity research. Eur Financ Manag 21:524-555

Barth ME, Hutton AP (2004) Analyst earnings forecast revisions and the pricing of accruals. Rev Account Stud 9:59-96

Batta GE, Qiu J, Yu F (2016) Credit derivatives and analyst behavior. Account Rev 91:1315-1343

Bhandari A, Mammadov B, Thevenot M (2018) The impact of executive inside debt on sell-side financial analyst forecast characteristics. Rev Quant Finan Account 51:283-315

Bhushan R (1989) Firm characteristics and analyst following. J Account Econ 11:255-274

Blackwell M, Iacus S, King G, Porro G (2009) CEM: coarsened exact matching in Stata. Stata J 9:524-546

Bradshaw MT, Richardson SA, Sloan RG (2001) Do analysts and auditors use information in accruals? J Account Res 39:45-74

Bradshaw M, Baginski SS, Wahlen J (2014) Financial reporting, financial statement analysis and valuation, 8th edn. Cengage learning, Boston

Bratten B, Gleason CA, Larocque SA, Mills LF (2017) Forecasting taxes: new evidence from analysts. Account Rev 92:1-29

Brennan MJ, Hughes PJ (1991) Stock prices and the supply of information. J Financ 46:1665-1691

Brown LD, Call AC, Clement MB, Sharp NY (2015) Inside the "black box" of sell-side financial analysts. J Account Res 53:1-47 
Brown JL, Drake KD, Martin MA (2016) Compensation in the Post-FIN 48 period: the case of contracting on tax performance and uncertainty. Contemp Account Res 33:121-151

Burgstahler DC, Eames MJ (2003) Earnings management to avoid losses and earnings decreases: are analysts fooled? Contemp Account Res 20:253-294

Cen L, Maydew E, Zhang L, Zuo L (2017) Customer-supplier relationships and corporate tax avoidance. J Financ Econ 123:377-394

Chang X, Dasgupta S, Hilary G (2006) Analyst coverage and financing decisions. J Finance 61:3009-3048

Chen T, Lin C (2017) Does information asymmetry affect corporate tax aggressiveness? J Financ Quant Anal 52:2053-2081

Chen X, Harford J, Li K (2007) Monitoring: which institutions matter? J Financ Econ 86:279-305

Chen S, Chen X, Cheng Q, Shevlin T (2010) Are family firms more tax aggressive than non-family firms? J Financ Econ 95:41-61

Chen H, Huang CT, Lin HWW (2016) Changes in analyst following for less covered firms accompanying regulation fair disclosure: the roles of ability and industry experience. Rev Quant Finan Account 46:519-541

Chen NX, Chiu P-C, Shevlin T (2018) Do analysts matter for corporate tax planning? Evidence from a natural experiment. Contemp Account Res 35:794-829

Cheng M, Subramanyam KR (2008) Analyst following and credit ratings. Contemp Account Res 25:1007-1043

Cheng CSA, Huang HH, Li Y, Stanfield J (2012) The effect of hedge fund activism on corporate tax avoidance. Account Rev 87:1493-1526

Clement MB, Hales J, Xue Y (2011) Understanding analysts' use of stock returns and other analysts' revisions when forecasting earnings. J Account Econ 51:279-299

Cohen RB, Gompers PA, Vuolteenaho T (2002) Who underreacts to cash-flow news? Evidence from trading between individuals and institutions. J Financ Econ 66:409-462

Comprix J, Graham R, Moore JA (2011) Empirical evidence on the impact of book-tax differences on divergence of opinion among investors. J Am Tax Assoc 33:51-78

Crabtree AD, Kubick TR (2014) Corporate tax avoidance and the timeliness of annual earnings announcements. Rev Quant Finan Account 42:51-67

Das S, Levine CB, Sivaramakrishnan K (1998) Earnings predictability and bias in analysts' earnings forecasts. Account Rev 73:277-294

Das S, Guo R-J, Zhang H (2006) Analysts' selective coverage and subsequent performance of newly public firms. J Finance 61:1159-1185

Desai MA, Dharmapala D (2006) Corporate tax avoidance and high-powered incentives. J Financ Econ 79:145-179

Desai MA, Dharmapala D (2009) Earnings management, corporate tax shelters, and book-tax alignment. Natl Tax J 62:169-186

Dhaliwal DS, Radhakrishnan S, Tsang A, Yang YG (2012) Nonfinancial disclosure and analyst forecast accuracy: international evidence on corporate social responsibility disclosure. Account Rev 87:723-759

Donohoe MP, Knechel WR (2014) Does corporate tax aggressiveness influence audit pricing? Contemp Account Res 31:284-308

Drake KD, Lusch SJ, Stekelberg J (2019) Does tax risk affect investor valuation of tax avoidance? J Account Audit Finance 34:151-176

Dyreng SD, Hanlon M, Maydew EL (2008) Long-run corporate tax avoidance. Account Rev 83:61-82

Elgers PT, Lo MH, Pfeiffer RJ Jr (2003) Analysts' vs. investors' weightings of accruals in forecasting annual earnings. J Account Public Policy 22:255-280

Emery DR, Li X (2009) Are the wall street analyst rankings popularity contests? J Financ Quant Anal 44:411-437

Erickson M, Hanlon M, Maydew EL (2004) How much will firms pay for earnings that do not exist? evidence of taxes paid on allegedly fraudulent earnings. Account Rev 79:387-408

Financial Accounting Standards Board (FASB) 2006 Accounting for Uncertainty in Income Taxes: An Interpretation of FASB Statement No. 109. FASB Interpretation No. 48, FASB, Norwalk, CT

Franco GD, Hope O-K, Larocque S (2015) Analysts' choice of peer companies. Rev Account Stud 20:82-109

Frank MM, Lynch LJ, Rego SO (2009) Tax reporting aggressiveness and its relation to aggressive financial reporting. Account Rev 84:467-496

Frankel R, Kothari SP, Weber J (2006) Determinants of the informativeness of analyst research. J Account Econ 41:29-54 
Gao L, Yang LL, Zhang JH (2016) Corporate patents, R\&D success, and tax avoidance. Rev Quant Finan Account 47:1063-1096

Gleason C, Mills L (2002) Reporting and recording of contingent tax liabilities. Account Rev 77:317-342

Gleason CA, Mills LF, Nessa ML (2018) Does FIN 48 improve firms' estimates of tax reserves? Contemp Account Res (forthcoming)

Goh BW, Lee J, Lim CY, Shevlin T (2016) The effect of corporate tax avoidance on the cost of equity. Account Rev 91:1647-1670

Gompers P, Metrick A (2001) Institutional investor and equity prices. Q J Econ 116:229-259

Gow ID, Ormazabal G, Taylor DJ (2010) Correcting for cross-sectional and time-series dependence in accounting research. Account Rev 85:483-512

Graham JR, Tucker AL (2006) Tax shelters and corporate debt policy. J Financ Econ 81:563-594

Graham JR, Hanlon M, Shevlin T, Shroff N (2014) Incentives for tax planning and avoidance: evidence from the field. Account Rev 89:991-1023

Gu F, Wang W (2005) Intangible assets, information complexity, and analysts' earnings forecasts. J Bus Financ Account 32:1673-1702

Guenther DA, Matsunaga SR, Williams BM (2017) Is tax avoidance related to firm risk? Account Rev 92:115-136

Gupta S, Laux R, Lynch D (2016) Do firms use tax reserves to meet analysts' forecasts? evidence from the Pre- and Post-FIN 48 periods. Contemp Account Res 33:1044-1074

Hadlock CJ, Pierce JR (2010) New evidence on measuring financial constraints: moving beyond the KZ index. Rev Financ Stud 23:1909-1940

Hanlon M (2005) The persistence and pricing of earnings, accruals, and cash flows when firms have large book-tax differences. Account Rev 80:137-166

Hanlon M, Heitzman S (2010) A review of tax research. J Account Econ 50:127-178

Hanlon M, Slemrod J (2009) What does tax aggressiveness signal? evidence from stock price reactions to news about tax shelter involvement. J Public Econ 93:126-141

Hanlon M, Krishnan GV, Mills LF (2012) Audit fees and book-tax differences. J Am Tax Assoc 34:55-86

Hao M, Forgione DA, Guo L, Zhang H (2017) Improvement in clinical trial disclosures and analysts' forecast accuracy: evidence from the pharmaceutical industry. Rev Quant Finan Account 49:785-810

Hasan I, Hoi CK, Wu Q, Zhang H (2014) Beauty is in the eye of the beholder: the effect of corporate tax avoidance on the cost of bank loans. J Financ Econ 113:109-130

He G, Marginson D, Dai X (2019) Do voluntary disclosures of product and business expansion plans impact analyst coverage and forecasts? Account Bus Res. https://doi.org/10.1080/00014788.2018.1559717

Healy PM, Hutton AP, Palepu KG (1999) Stock performance and intermediation changes surrounding sustained increases in disclosure. Contemp Account Res 16:485-520

Hodder L, Hopkins PE, Wood DA (2008) The effects of financial statement and informational complexity on analysts' cash flow forecasts. Account Rev 83:915-956

Hong H, Kubik JD (2003) Analyzing the analysts: career concerns and biased earnings forecasts. J Financ 58:313-351

Hope O-K, Thomas WB, Winterbotham G (2009) Geographic earnings disclosure and trading volume. J Account Public Policy 28:167-188

Hope O-K, Ma M, Thomas WB (2013) Tax avoidance and geographic earnings disclosure. J Account Econ 56:170-189

Hribar P, Collins D (2002) Errors in estimating accruals: implications for empirical research. J Account Res 40:105-134

Huddart SJ, Ke B (2007) Information asymmetry and cross-sectional variation in insider trading. Contemp Account Res 24:195-232

Iacus SM, King G, Porro G (2011) Causal inference without balance checking: coarsened exact matching. Polit Anal 20:1-24

Irani AJ, Karamanou I (2003) Regulation Fair disclosure, analyst following, and analyst forecast dispersion. Account Horiz 17:15-29

Irani RM, Oesch D (2013) Monitoring and corporate disclosure: evidence from a natural experiment. J Financ Econ 109:398-418

Isin AA (2018) Tax avoidance and cost of debt: the case for loan-specific risk mitigation and public debt financing. J Corp Financ 49:344-378

Jin C, Li T, Zheng SX (2016) IPO offering size and analyst forecasts. Rev Pac Basin Financ Mark Policies 19:1-25

Ke B, Yu Y (2006) The effect of issuing biased earnings forecasts on analysts' access to management and survival. J Account Res 44:965-999 
Kim J-B, Li Y, Zhang L (2011) Corporate tax avoidance and stock price crash risk: firm-level analysis. J Financ Econ 100:639-662

Kuo NT, Lee CF (2016) A potential benefit of increasing book-tax conformity: evidence from the reduction in audit fees. Rev Account Stud 21:1287-1326

Lang MH, Lundholm RJ (1996) Corporate disclosure policy and analyst behavior. Account Rev 71:467-492

Lee C, So EC (2017) Uncovering expected returns: information in analyst coverage proxies. J Financ Econ 124:331-348

Lennox C, Lisowsky P, Pittman J (2013) Tax aggressiveness and accounting fraud. J Account Res 51:739-778

Lev B, Nissim D (2004) Taxable income, future earnings, and equity values. Account Rev 79:1039-1074

Li W, Pittman J, Wang Z (2018) The determinants and consequences of tax audits: some evidence from China. J Am Tax Assoc. https://doi.org/10.2308/atax-52136

Lim T (2001) Rationality and analysts' forecast bias. J Financ 56:369-385

Lin MC, Ho PH, Chih HL (2018) Effects of managerial overconfidence on analyst recommendations. Rev Quant Finan Acc. https://doi.org/10.1007/s11156-018-0743-4

Lisowsky P, Robinson L, Schmidt A (2013) Do publicly disclosed tax reserves tell us about privately disclosed tax shelter activity? J Account Res 51:583-629

Manzon G, Plesko G (2002) The relation between financial and tax reporting measures of income. Tax Law Rev 55:175-214

Marcus B, Wallace S (1991) Competing in the New Capital Markets: Investor Relations Strategies for the 1990s. Harper Business, New York

Menichini AA (2017) On the value and determinants of the interest tax shields. Rev Quant Finance Account 48:725-748

Mikhail MB, Walther BR, Willis RH (1999) Does forecast accuracy matter to security analysts? Account Rev 74:185-200

Mills LF (1998) Book-tax differences and internal revenue service adjustments. J Account Res 36:343-356

Mills LF, Newberry KJ (2001) The influence of tax and nontax costs on book-tax reporting differences: public and private firms. J Am Tax Assoc 23:1-19

Mohanram PS, Sunder SV (2006) How has regulation FD affected the operations of financial analysts? Contemp Account Res 23:491-525

O'Brien RM (2007) A caution regarding rules of thumb for variance inflation factors. Qual Quant 41:673-690

O’Brien PC, Bhushan R (1990) Analyst following and institutional ownership. J Account Res 28:55-76

Palepu K, Healy J, Bernard V (2000) Business Analysis and Valuation. Using Financial Statements. South-Western College Publishing, Cincinnati

Palepu KG, Healy PM, Peek E (2016) Business analysis and valuation: IFRS edition, 4th edn. Thomson South-Western, Mason

Petersen MA (2009) Estimating standard errors in finance panel data sets: comparing approaches. Rev Financ Stud 22:435-480

Robinson LA, Schmidt AP (2013) Firm and investor responses to uncertain tax benefit disclosure requirements. J Am Tax Assoc 35:85-120

Robinson LA, Stomberg B, Towery EM (2016) One size does not fit all: how the uniform rules of FIN 48 affect the relevance of income tax accounting. Account Rev 91:1195-1217

Robinson LA, Savor P, Sikes S (2017) Do investors view income tax expense as less value-relevant post FIN 48? Working paper. University of Pennsylvania

Roger T (2018) The coverage assignments of financial analysts. Account Bus Res 48:651-673

Salerno D (2014) The role of earnings quality in financial analyst forecast accuracy. J Appl Bus Res 30:255-276

Smith CW, Watts RL (1992) The investment opportunity set and corporate financing, dividend, and compensation policies. J Financ Econ 32:263-292

Stickel SE (1990) Predicting individual analyst earnings forecasts. J Account Res 28:409-417

Thompson SB (2011) Simple formulas for standard errors that cluster by both firm and time. J Financ Econ 99:1-10

Weber DP (2009) Do analysts and investors fully appreciate the implications of book-tax differences for future earnings? Contemp Account Res 26:1175-1206

Wilde JH, Wilson RJ (2018) Perspectives on corporate tax planning: observations from the past decade. J Am Tax Assoc 40:63-81

Wilson RJ (2009) An examination of corporate tax shelter participants. Account Rev 84:969-999

Wooldridge JM (2016) Introductory econometrics: A modern approach, 6th edn. Cengage Learning, Boston 
Wu JS, Zang AY (2009) What determine financial analysts' career outcomes during mergers? J Account Econ 47:59-86

Yan X, Zhang Z (2009) Institutional investors and equity returns: are short-term institutions better informed? Rev Financ Stud 22:893-924

Yu F (2008) Analyst coverage and earnings management. J Financ Econ 88:245-271

Publisher's Note Springer Nature remains neutral with regard to jurisdictional claims in published maps and institutional affiliations. 